Prepared in cooperation with the Federal Emergency Management Agency

\title{
Characterization of Peak Streamflows and Flood Inundation at Selected Areas in North Carolina Following Hurricane Matthew, October 2016
}

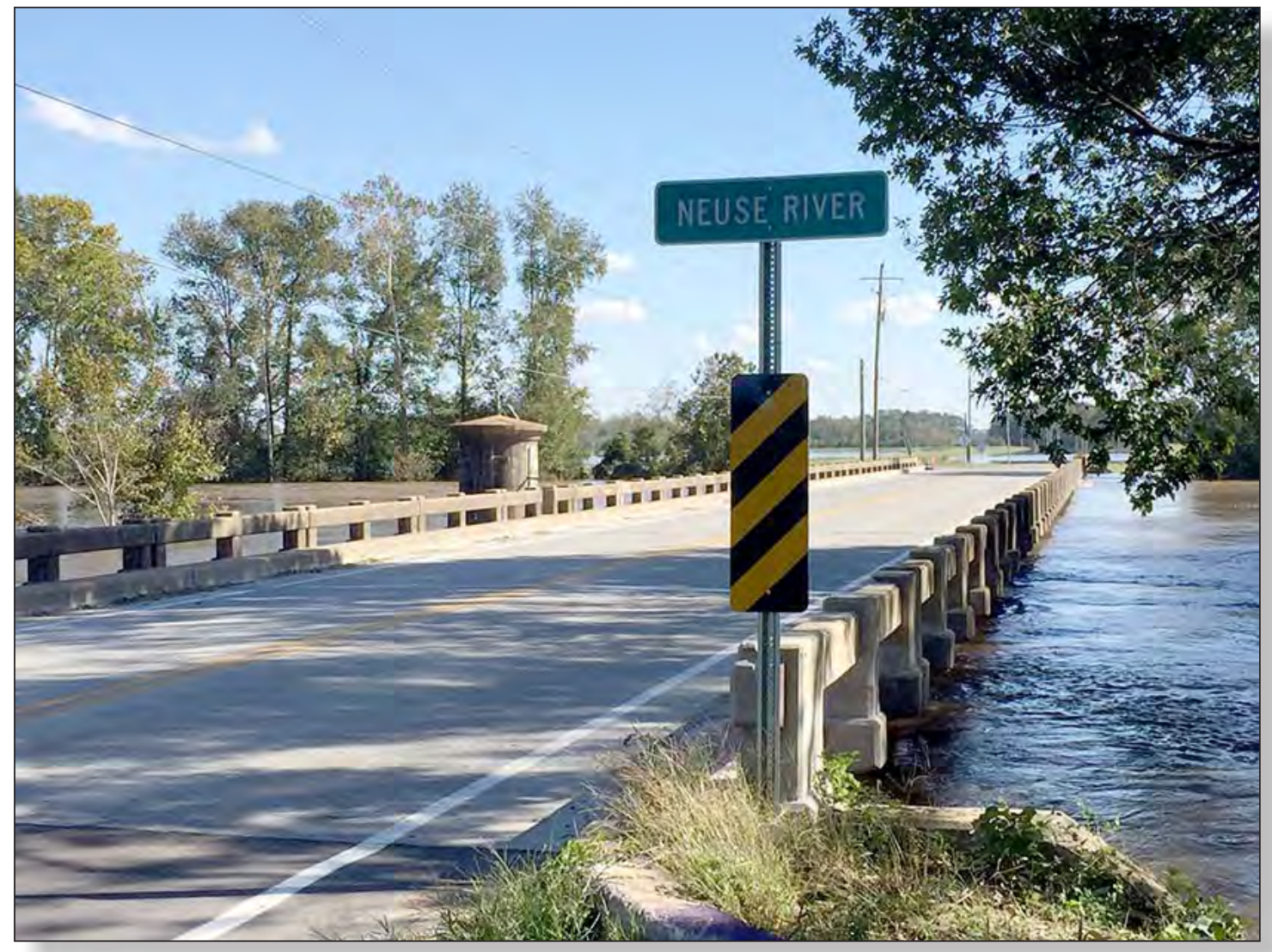

Open-File Report 2017-1047

Version 2.0, August 2017 
Front cover. U.S. Geological Survey (USGS) streamgaging station Neuse River near Goldsboro (02089000), Wayne County, North Carolina. Photograph by Eric Rudisill, USGS.

Back cover. USGS hydrologist documenting a high-water mark in Lumberton, North Carolina. Photograph by Jonathan Musser, USGS. 


\section{Characterization of Peak Streamflows and Flood Inundation at Selected Areas in North Carolina Following Hurricane Matthew, October 2016}

By Jonathan W. Musser, Kara M. Watson, and Anthony J. Gotvald

Prepared in cooperation with the Federal Emergency Management Agency

Open-File Report 2017-1047

Version 2.0, August 2017 


\title{
U.S. Department of the Interior \\ RYAN K. ZINKE, Secretary
}

\section{U.S. Geological Survey William H. Werkheiser, Acting Director}

\author{
U.S. Geological Survey, Reston, Virginia \\ First release: 2017 \\ Revised: June 2017 (ver. 1.1) \\ Revised: August 2017 (ver. 2.0)
}

For more information on the USGS —-the Federal source for science about the Earth, its natural and living resources, natural hazards, and the environment-visit https://www.usgs.gov or call 1-888-ASK-USGS.

For an overview of USGS information products, including maps, imagery, and publications,

visit https://store.usgs.gov.

Any use of trade, firm, or product names is for descriptive purposes only and does not imply endorsement by the U.S. Government.

Although this information product, for the most part, is in the public domain, it also may contain copyrighted materials as noted in the text. Permission to reproduce copyrighted items must be secured from the copyright owner.

Suggested citation:

Musser, J.W., Watson, K.M., and Gotvald, A.J., 2017, Characterization of peak streamflows and flood inundation at selected areas in North Carolina following Hurricane Matthew, October 2016 (ver. 2.0, August 2017): U.S. Geological Survey Open-File Report 2017-1047, 24 p., https://doi.org/10.3133/ofr20171047.

ISSN 2331-1258 (online) 


\section{Contents}

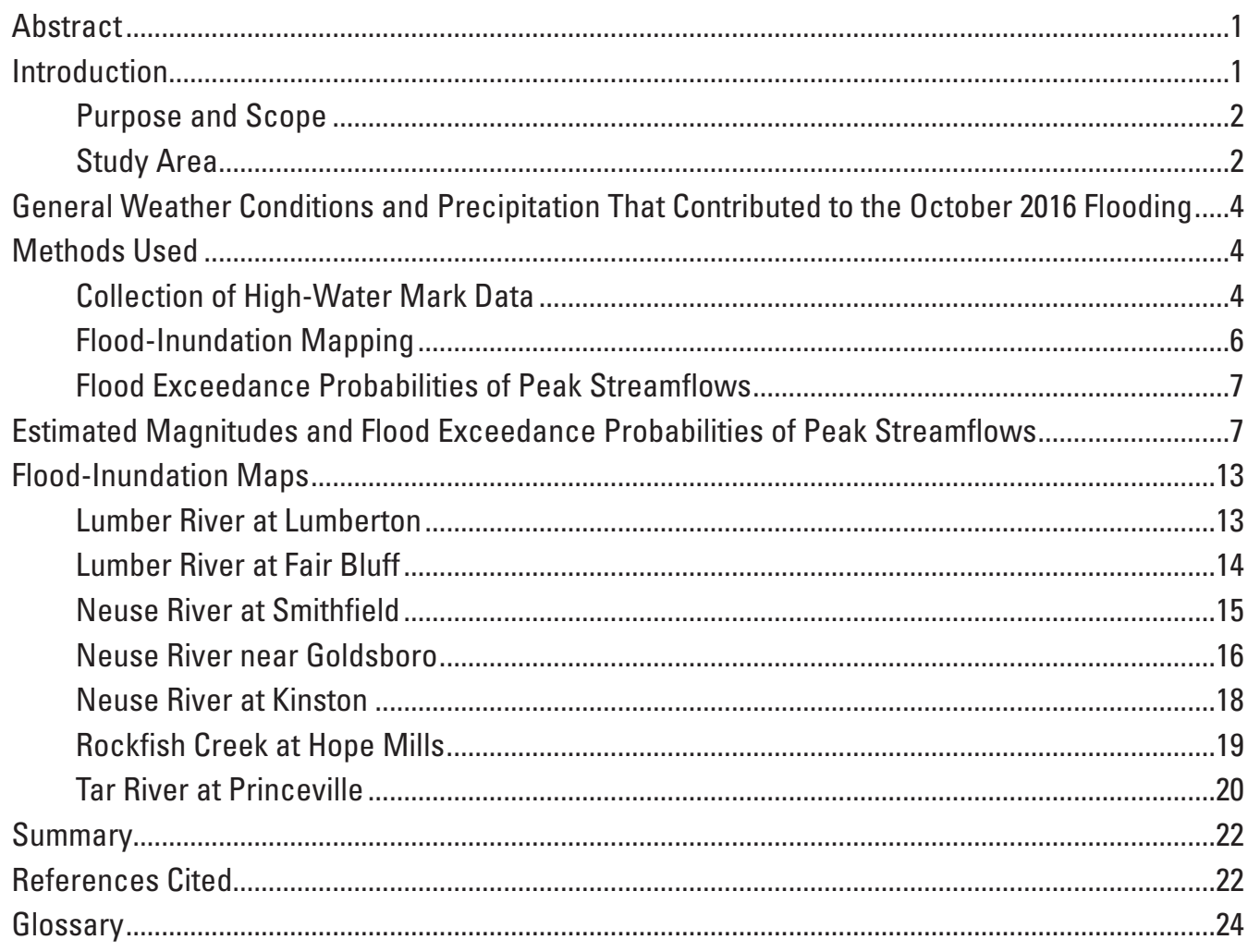

\section{Figures}

1. Hurricane Matthew storm total rainfall, October 4-10, 2016...........................................1

2. Study area showing location of flood-inundation mapping sites and streamgaging stations in eastern North Carolina

3. Cumulative rainfall October 7-9, 2016, for southeast North Carolina and northeast South Carolina .............................................................................................................

4. Flood-inundation map, Lumber River at Lumberton, North Carolina, October 2016 ........13

5. Flood-inundation map, Lumber River at Fair Bluff, North Carolina, October 2016...........14

6. Flood-inundation map, Neuse River at Smithfield, North Carolina, October 2016 ...........15

7. Flood-inundation map, Neuse River near Goldsboro, North Carolina, October 2016......17

8. Flood-inundation map, Neuse River at Kinston, North Carolina, October 2016 ..............18

9. Flood-inundation map, Rockfish Creek at Hope Mills, North Carolina, October 2016.....19

10. Flood-inundation map, Tar River at Princeville, North Carolina, October 2016 ...............21 


\section{Tables}

1. Communities, waterbodies, counties, reach lengths, and number of high-water marks used to generate flood-inundation maps

2. Selected recurrence intervals and the associated annual exceedance probabilities ....7

3. Flood-peak gage heights, peak streamflows, and estimated annual exceedance probabilities for the October 2016 flood at selected U.S. Geological Survey streamgages in North Carolina

4. Flood-frequency statistics for selected U.S. Geological Survey streamgages in North Carolina.

\section{Conversion Factors}

U.S. customary units to International System of Units

\begin{tabular}{lcl} 
& Multiply & \multicolumn{1}{c}{ Bo obtain } \\
\hline & Length & \\
\hline inch (in.) & 2.54 & centimeter $(\mathrm{cm})$ \\
inch (in.) & 25.4 & millimeter $(\mathrm{mm})$ \\
foot (ft) & 0.3048 & meter $(\mathrm{m})$ \\
mile (mi) & 1.609 & kilometer $(\mathrm{km})$ \\
\hline & Area & \\
\hline square mile $\left(\mathrm{mi}^{2}\right)$ & 259.0 & hectare $(\mathrm{ha})$ \\
square mile $\left(\mathrm{mi}^{2}\right)$ & 2.590 & square kilometer $\left(\mathrm{km}^{2}\right)$ \\
\hline & Flow rate & \\
\hline cubic foot per second $\left(\mathrm{ft}^{3} / \mathrm{s}\right)$ & 0.02832 & cubic meter per second $\left(\mathrm{m}^{3} / \mathrm{s}\right)$ \\
\hline
\end{tabular}

International System of Units to U.S. customary units

\begin{tabular}{lll}
\hline \multicolumn{1}{c}{ Multiply } & \multicolumn{1}{c}{ By } & To obtain \\
\hline & Length & \\
\hline centimeter $(\mathrm{cm})$ & 0.3937 & inch (in.) \\
meter $(\mathrm{m})$ & 3.281 & foot $(\mathrm{ft})$ \\
meter $(\mathrm{m})$ & 1.094 & yard $(\mathrm{yd})$ \\
\hline
\end{tabular}




\section{Datum}

Vertical coordinate information is referenced to the North American Vertical Datum of 1988 (NAVD 88) and the National Geodetic Vertical Datum of 1929 (NGVD 29).

Horizontal coordinate information is referenced to the North American Datum of 1983 (NAD 83).

Elevation, as used in this report, refers to distance above the vertical datum.

\section{Abbreviations}

$\begin{array}{ll}\text { AEP } & \text { annual exceedance probability } \\ \text { DEM } & \text { digital elevation model } \\ \text { FEMA } & \text { Federal Emergency Management Agency } \\ \text { GIS } & \text { geographic information system } \\ \text { GPS } & \text { Global Positioning System } \\ \text { HWM } & \text { high-water mark } \\ \text { lidar } & \text { light detection and ranging } \\ \text { NCEM } & \text { North Carolina Emergency Management } \\ \text { NCGS } & \text { North Carolina Geodetic Survey } \\ \text { NOAA } & \text { National Oceanic and Atmospheric Administration } \\ \text { STN } & \text { Short-Term Network } \\ \text { USACE } & \text { U.S. Army Corps of Engineers } \\ \text { USGS } & \text { U.S. Geological Survey }\end{array}$





\title{
Characterization of Peak Streamflows and Flood Inundation at Selected Areas in North Carolina Following Hurricane Matthew, October 2016
}

\author{
By Jonathan W. Musser, Kara M. Watson, and Anthony J. Gotvald
}

\section{Abstract}

The passage of Hurricane Matthew through central and eastern North Carolina during October 7-9, 2016, brought heavy rainfall, which resulted in major flooding. More than 15 inches of rain was recorded in some areas. More than 600 roads were closed, including Interstates 95 and 40, and nearly 99,000 structures were affected by floodwaters. Immediately following the flooding, the U.S. Geological Survey documented 267 high-water marks, of which 254 were surveyed. North Carolina Emergency Management documented and surveyed 353 high-water marks. Using a subset of these high-water marks, seven floodinundation maps were created for hard-hit communities. Digital datasets of the inundation areas, study reach boundary, and water-depth rasters are available for download. In addition, peak gage-height data, peak streamflow data, and annual exceedance probabilities (in percent) were determined for 24 U.S. Geological Survey streamgages located near the heavily flooded communities.

Figure 1. Hurricane Matthew storm total rainfall, 0 ctober 4-10, 2016 (Southeast Regional Climate Center, 2016).

\section{Introduction}

Hurricane Matthew brought heavy rainfall to parts of the Southeastern United States, including North Carolina, during October 7-9, 2016. The heavy rainfall resulted in major flooding in central and eastern North Carolina. Rainfall totals of 3 inches to more than 15 inches were widespread throughout the area (fig. 1; Southeast Regional Climate Center, 2016).

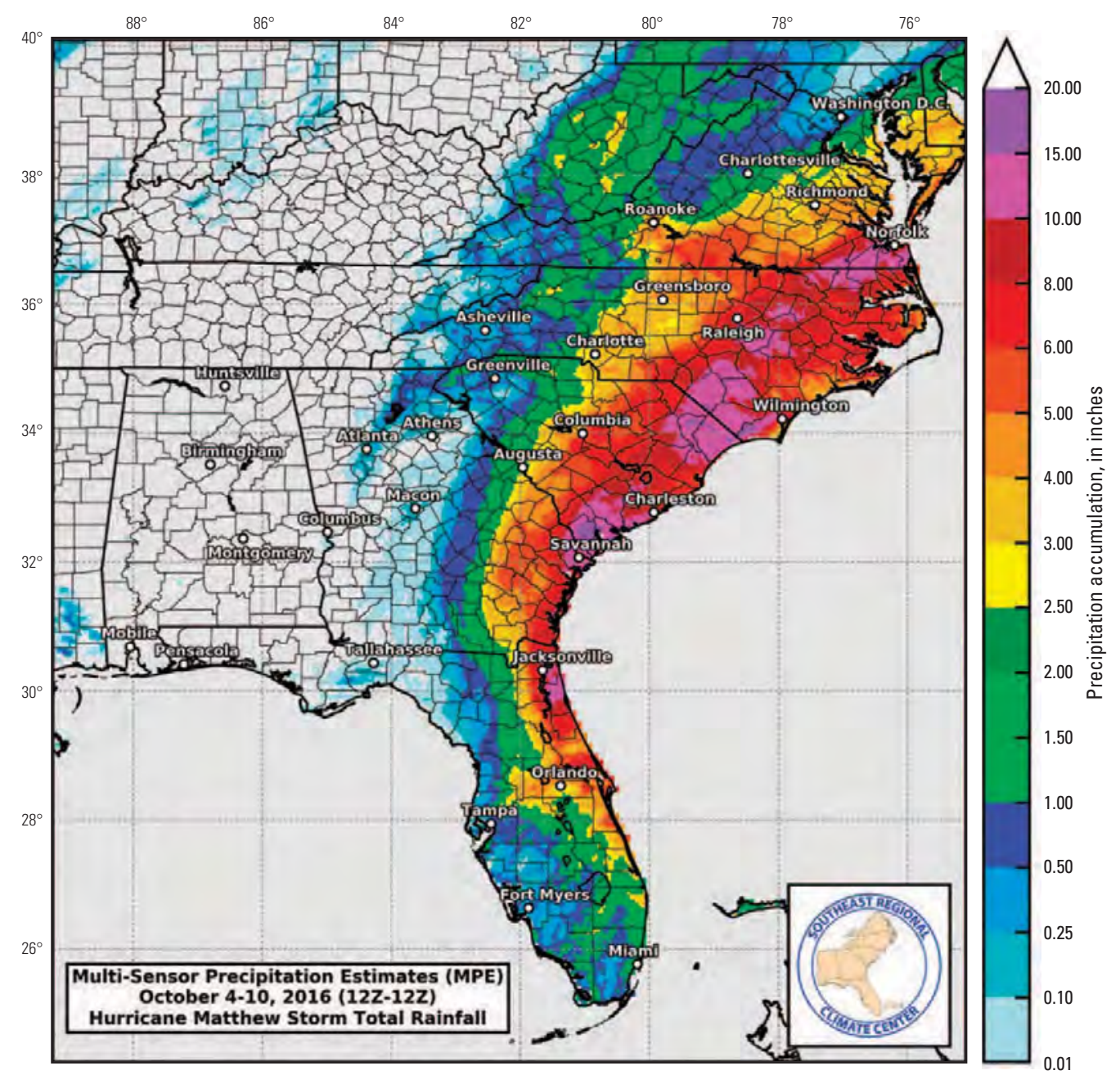


By the end of October, flooding from the passage of Hurricane Matthew had resulted in 28 fatalities in North Carolina, of which 17 were associated with vehicles that were swept off flooded roadways (Stradling, 2016). At the height of the event more than 600 roads had to be closed in North Carolina, including portions of Interstates 40 and 95. More than 2,100 road repairs were required to fix shoulder washouts and damages to drainage structures such as pipes, reinforced concrete box culverts, and bridges (Matthew Lauffer, N.C. Department of Transportation, written commun., November 30, 2016). The N.C. Department of Public Safety's Floodplain Mapping Program reported that nearly 99,000 structures across the State were affected by floodwaters. Emergency management officials have estimated damage in North Carolina from the storm at approximately $\$ 1.5$ billion, not including damage to the State infrastructure or the agriculture industry (Nicholas Petro, National Oceanic and Atmospheric Administration, National Weather Service, written commun., November 9, 2016). On the basis of historical information compiled by the State Climate Office of North Carolina, Hurricane Matthew was the fourth costliest and fifth deadliest tropical cyclone on record in North Carolina (State Climate Office of North Carolina, 2015). In the aftermath of the October 2016 flooding, the U.S. Geological Survey (USGS) and the Federal Emergency Management Agency (FEMA) initiated a cooperative study to map the extent of flooding in seven communities in North Carolina, evaluate the magnitude of the flood, and determine the exceedance probability for 24 streamgages located in and around these communities.

\section{Purpose and Scope}

The purpose of this report is to document the collection, processing, and presentation of data by the USGS in support of FEMA response-and-recovery operations following the October 2016 flood event throughout central and eastern North Carolina from rainfall associated with Hurricane Matthew. The technical scope of the report includes (1) description of the atmospheric conditions, the temporal and spatial patterns of rainfall that triggered the flooding, and a narrative of the flood and its effects, (2) analysis of peak-flow magnitudes and the statistical exceedance probabilities at selected locations, (3) the identification and surveying of high-water marks (HWM), and (4) the geographic information system (GIS) analysis of HWM locations and elevations to produce flood-inundation maps (areal extent and depth of flooding) for seven heavily flooded communities in North Carolina.

\section{Study Area}

The study area description is extracted from a previously published companion report "Preliminary Peak Stage and Streamflow Data at Selected Streamgaging Stations in North Carolina and South Carolina for Flooding Following Hurricane Matthew, October 2016" (Weaver and others, 2016). North Carolina is located on the South Atlantic slope adjacent to the Atlantic Ocean and is generally divided into three major physiographic provinces: Blue Ridge, Piedmont, and Coastal Plain (Cooke, 1936; fig. 2). The communities and streamgages discussed in this report are all located in the Piedmont or Coastal Plain Provinces.

The Piedmont Province is characterized by rolling hills, elongated ridges, and moderately deep to shallow valleys. Piedmont land-surface elevations range from about 1,000 feet (ft) above sea level at the Blue Ridge foothills to about $300-400 \mathrm{ft}$ above sea level at the Fall Line, which is the name given to the boundary between the Piedmont and Coastal Plain regions (fig. 2).

The Coastal Plain Province in North Carolina comprises about one-third of the State's total area and is overlain by a sedimentary wedge that thickens from a featheredge at the Fall Line to more than $10,000 \mathrm{ft}$ at Cape Hatteras at the Outer Banks (Giese and Mason, 1993; Winner and Coble, 1996). At the Fall Line, a narrow, hilly subregion of the Coastal Plain, known as the Sand Hills, provides a transition zone between the Piedmont and Coastal Plain. The Sand Hills region is about 30 to 40 miles (mi) wide, with elevations ranging from about 200 to more than $500 \mathrm{ft}$. The lower part of the Coastal Plain consists of low-elevation, flat plains with many swamps, marshes, dunes, barrier islands, and beaches, which typically are lower, flatter, and more poorly drained than the upper part of the Coastal Plain (Omernik, 1987).

In North Carolina, precipitation is primarily delivered by storms that move inland from the Gulf of Mexico, the Caribbean Sea, and the Atlantic Ocean (U.S. Geological Survey, 1985). Additionally, local and upwind land surfaces, as well as lakes and reservoirs, provide moisture to the atmosphere by evaporation. In a normal year, monthly precipitation is highest in the winter, reaching a maximum in early March and then decreasing sharply in April and May. Fall is typically a dry season except in rare instances when tropical storms or hurricanes occur.

The average annual precipitation in the Piedmont ranges from about 40 inches in the west to about 50 inches in the east in the vicinity of the Fall Line (State Climate Office of North Carolina, 2016). Average annual precipitation in the Coastal Plain generally ranges from 50 to 55 inches, with higher values near 60 inches where tropical storms have affected parts of the southern coastal region of North Carolina. 


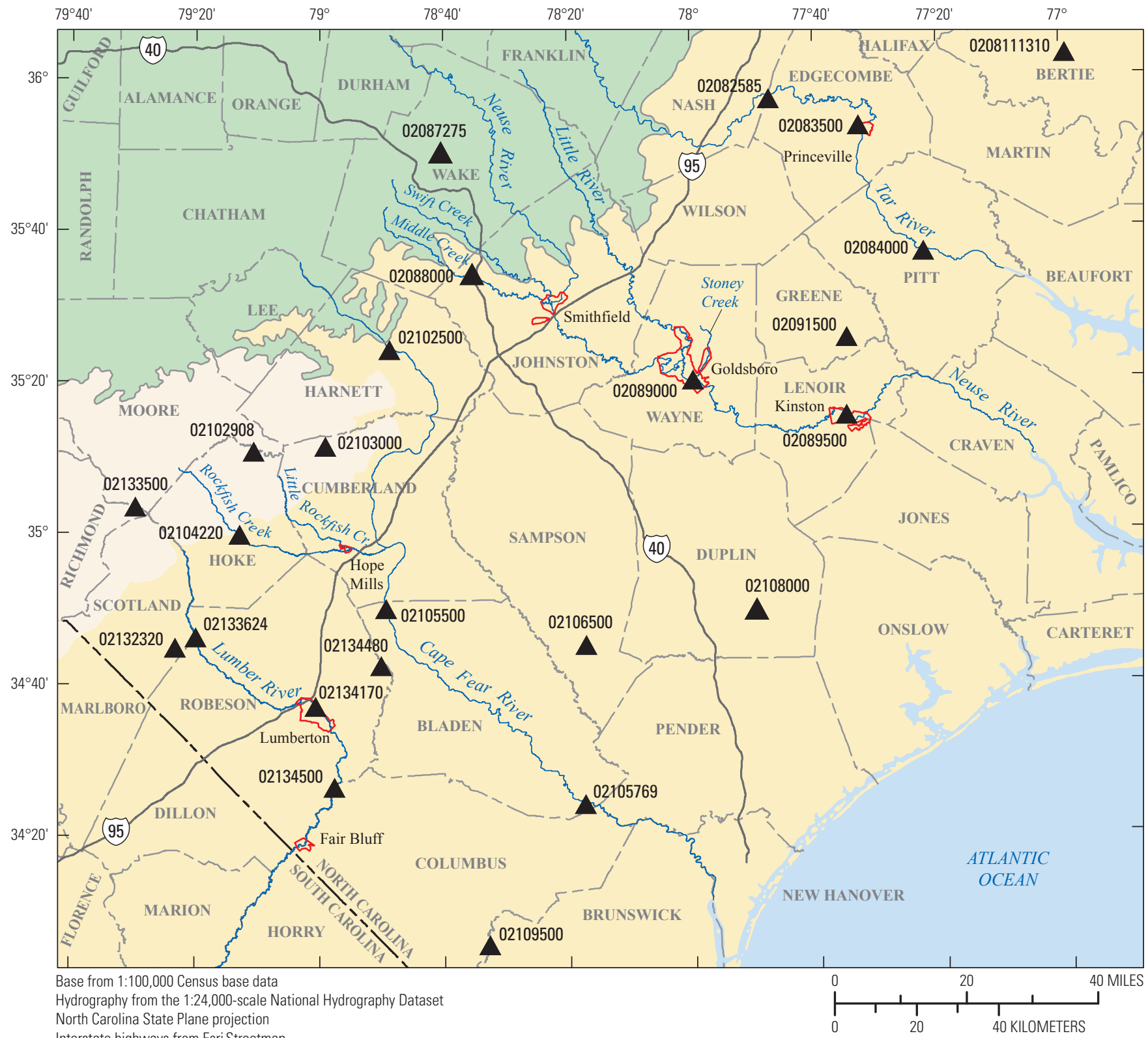

North Carolina State Plane pring

Interstate highways from Esri Streetmap
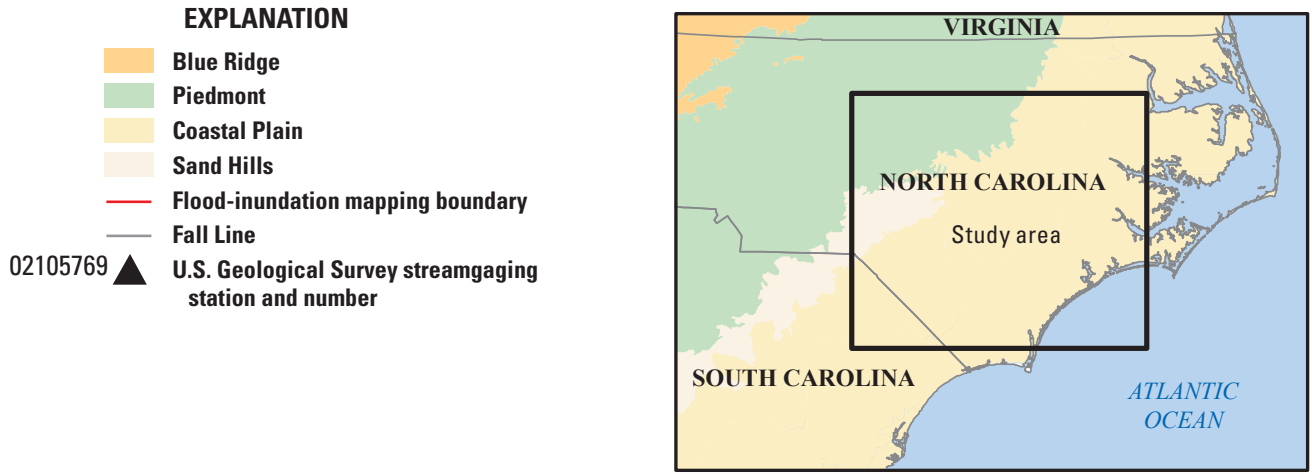

Location of study area in North Carolina

Figure 2. Study area showing location of flood-inundation mapping sites and streamgaging stations in eastern North Carolina. 


\section{General Weather Conditions and Precipitation That Contributed to the October 2016 Flooding}

Rainfall from Hurricane Matthew in central and eastern North Carolina - the area most affected by flooding — occurred during October 7-9, 2016, and resulted in all-time record 1-day amounts for a number of locations across the region, with periods of climatic record ranging from 18 to 146 years (commonly $50+$ years) (Nicholas Petro, National Oceanic and Atmospheric Administration, National Weather Service, written commun., November 9, 2016). One-day records were set at four locations in North Carolina: Tarboro (9.50 inches, tying previous record set on October 25, 1872; records back to 1870); Fayetteville (14.00 inches, surpassing 5.13 inches previously set just 10 days prior on September 29, 2016; Lumberton (12.53 inches, surpassing 7.62 inches set on September 15, 1999; records back to 1948); and Raleigh (6.45 inches; Weaver and others, 2016). At the USGS raingage at Cape Fear River at William O. Huske Lock near Tarheel in Bladen County, North Carolina (02105500), a total of 16.87 inches was recorded during October 7-9 (Weaver and others, 2016). The cumulative total rainfall estimate for the area ranged from 4.1 to 14.7 inches in the Neuse River Basin, from 4.6 to 16.1 inches in the Lumber River Basin, from 4.4 to 13.2 inches in the Tar River Basin, and from 6.9 to 13.8 inches in the Rockfish Creek Basin (fig. 3; National Weather Service, 2017). For a more detailed discussion about the weather conditions, see Weaver and others (2016).

\section{Methods Used}

The methods used to identify, document, and reference the HWMs resulting from flooding as well as the methods used to create flood-inundation maps using these HWMs are discussed in this section. Also discussed are the methods by which the estimation of flood magnitude and frequency were developed through analysis of the annual peak streamflows at 24 USGS streamgages, 3 of which are located within the areas of the flood-inundation maps. All streamflow data used in support of this report can be accessed from the USGS National Water Information System (U.S. Geological Survey, 2017b).

\section{Collection of High-Water Mark Data}

High-water marks are the evidence of the highest water levels during a flood and provide valuable data for understanding flood events. The USGS followed the guidance provided by Koenig and others (2016) for identification and documentation of HWMs. The best HWMs are formed from small seeds or floating debris that are carried by floodwaters and that adhere to smooth surfaces or are lodged in tree bark to form a distinct line. Stain lines on buildings, fences, and other structures also provide excellent marks. High-water marks are best identified immediately following the peak stage of a flood event, because time and weather (wind, rain, sun) may blow, wash, or fade away the evidence of the peak water line. Care was taken to identify HWMs as far from the main channel as feasible, where velocities generally are slow and where wave action and pileup or drawdown effects of fast-moving waters are best avoided. Information about the HWMs identified by the USGS for this flood event was made available to the public through the USGS Short-Term Network (STN; U.S. Geological Survey, 2016), which is an online interface created to facilitate the timely dissemination of field data. Additional information, including a download portal for HWM information, is available from the USGS Hurricane Matthew web page at https://water.usgs.gov/floods/ events/2016/matthew/ (U.S. Geological Survey, 2017a).

Identification of HWMs, by the USGS, began on October 9 and continued through October 24, 2016. After an acceptable HWM was found, a more permanent identification mark was established, such as a Parker-Kalon (PK) nail, disk, stake, chiseled mark, or paint line; if possible, the identification marks were accompanied by orange flagging. Written descriptions, sketches, photographs, and Global Positioning System (GPS) horizontal measurements obtained with a hand-held GPS unit were made, so the marks could easily be found later, and surveyed to the standard vertical datum, North American Vertical Datum of 1988 (NAVD 88). The USGS field crews identified 267 HWMs in North Carolina with a depth above land-surface measurement made in feet, and 254 of these HWMs were surveyed for elevation above NAVD 88. North Carolina Emergency Management (NCEM) also identified and surveyed $353 \mathrm{HWMs}$. Information about these HWMs can be obtained by contacting NCEM directly.

During the mapping process, the HWMs used to create flood-inundation maps were checked for location and elevation accuracy by comparing field note diagrams and descriptions to aerial photography and detailed street and parcel maps. If the location could not be determined accurately or the elevation was substantially different from other HWMs in the area, the HWM was not used. Also, some HWMs were not used because they were the result of localized flooding of small areas and did not represent the water-surface elevation of the surrounding area. 


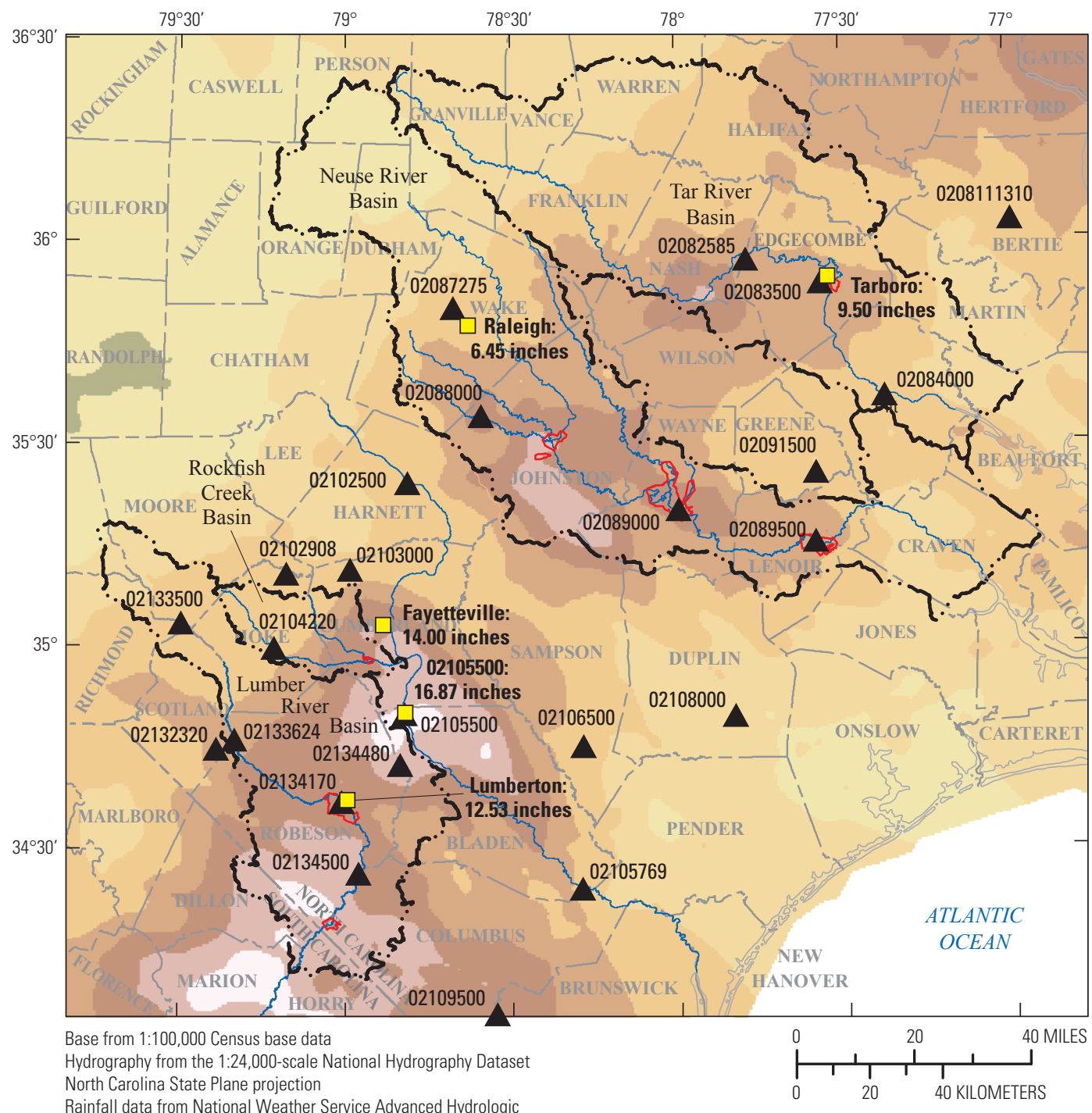

Rainfall data from National Weather Service Advanced Hydrologic

Prediction Service

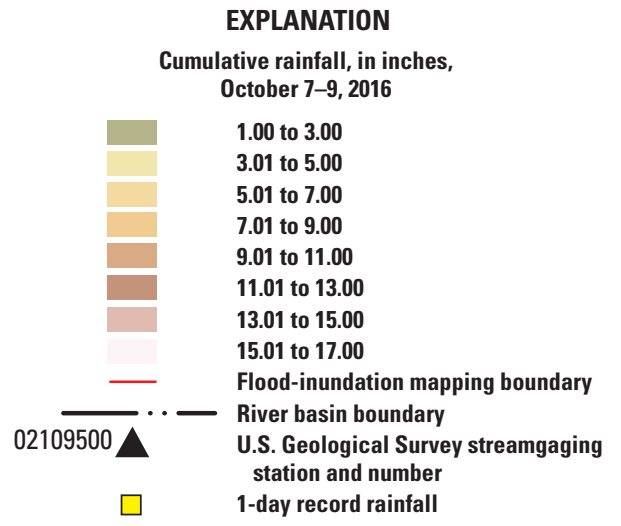

Figure 3. Cumulative rainfall October 7-9, 2016, for southeast North Carolina and northeast South Carolina. 


\section{Flood-Inundation Mapping}

Flood-inundation maps were created using a GIS for seven communities near affected rivers in central and eastern North Carolina (fig. 2). The flood-inundation maps were used to estimate the aerial extent and depth of flooding that correspond to the HWMs identified and surveyed by USGS and NCEM hydrographers following the flood event. Table 1 lists the community, county, waterbodies, reach lengths, and number of HWMs used to generate the flood-inundation maps. The first step in the generation of the flood-inundation maps was the creation of a flood-elevation raster surface. Flood extent and depth surfaces were created independently for each community, using the HWM elevations, cross sections across the direction of flow at the HWMs and streamgages, and a GIS interpolation technique - the ArcGIS "Topo-to-Raster" tool (http://pro.arcgis.com/en/pro-app/tool-reference/3d-analyst/ how-topo-to-raster-works.htm, accessed January 2015) as described by Musser and others (2016). In one case, a constant flood-elevation surface was used on a lake which only had one HWM. A geographic limit was placed on the extent of the generated surface on the basis of the distribution of HWMs and an understanding of the natural hydrologic flow in the area of each community.
The flood-elevation surface that was created by using GIS interpolation was then combined with a 3.125 -ft cell size digital elevation model (DEM). The DEM was derived from light detection and ranging (lidar) data with an 18.2-centimeter vertical root-mean-square-error and a 0.07 -meter or better nominal point spacing (North Carolina Floodplain Mapping Program, 2016). An inundated area was depicted where the flood-elevation surface was higher than the DEM land surface. The depth of flooding was determined as the difference between the flood-elevation surface and the DEM land surface. Because of the large number of bridges in the mapped reaches, the inundation surfaces were not clipped to show any bridges that were not inundated.

Uncertainties in the mapped extent and depth of flooding exist within the maps because of the mapping methods used and the number and spatial distribution of HWMs in a given mapped reach. Hydraulic models were not used to determine the extent or depth of flood inundation. The flood-elevation surfaces were all created using interpolation between cross sections drawn through the best available HWM elevations rather than hydraulic models. Changes in land-surface features in flood plains, timing of the flooding that may differ between the smaller inflow tributaries and the larger main stem tributaries, and the intermingling of flows from adjacent streams

Table 1. Communities, waterbodies, counties, reach lengths, and number of high-water marks used to generate flood-inundation maps.

\begin{tabular}{|c|c|c|c|c|}
\hline Community & $\begin{array}{l}\text { Waterbody or } \\
\text { waterbodies }\end{array}$ & County or counties & $\begin{array}{l}\text { Reach } \\
\text { length } \\
\text { (miles) }\end{array}$ & $\begin{array}{l}\text { Number of high-water } \\
\text { marks used to generate } \\
\text { flood-inundation map } \\
\text { for each community }\end{array}$ \\
\hline Fair Bluff & Lumber River & Columbus, Robeson & 3.5 & 5 \\
\hline \multirow[t]{3}{*}{ Goldsboro } & Neuse River & Wayne & 20.8 & 20 \\
\hline & Little River & & 11.8 & \\
\hline & Stoney Creek & & 6.3 & \\
\hline \multirow[t]{2}{*}{ Hope Mills } & Rockfish Creek & Cumberland & 1.5 & 7 \\
\hline & Little Rockfish Creek & & 3.2 & \\
\hline \multirow[t]{2}{*}{ Kinston } & Neuse River & Lenoir & 9.3 & 10 \\
\hline & Southwest Creek & & 5.0 & \\
\hline \multirow[t]{3}{*}{ Lumberton } & Lumber River & Robeson & 11.5 & 24 \\
\hline & Little Jacob Swamp & & 2.3 & \\
\hline & Jacob Branch & & 3.1 & \\
\hline Princeville & Tar River & Edgecombe & 2.1 & 12 \\
\hline \multirow[t]{4}{*}{ Smithfield } & Neuse River & Johnston & 4.8 & 10 \\
\hline & Swift Creek & & 2.6 & \\
\hline & Middle Creek & & 2.4 & \\
\hline & Holts Lake & & 2.6 & \\
\hline
\end{tabular}


cannot be accounted for without the use of hydraulic models. In locations where HWMs are spaced farther apart, there is a greater possibility of decreased accuracy of spatial interpretation of the extent and depth of flood inundation. Within a given mapped area, some extrapolation was performed beyond the most upstream and downstream HWMs. In many cases, the boundary was extended to some anthropogenic structure, such as a road or bridge crossing.

\section{Flood Exceedance Probabilities of Peak Streamflows}

Information commonly needed by emergency managers and water resources engineers immediately after a major flood includes the expected frequency of peak discharges for the flow magnitudes observed during the event. Flood-frequency analyses for streamgages with sufficient record can provide insight into the occurrence or likelihood of peak discharges of varying magnitudes. The annual exceedance probability (AEP) for a particular streamflow is the probability of that streamflow being equaled or exceeded in any given year. For example, an AEP of 0.01 means there is a 1 percent $(\mathrm{AEP} \times 100)$ chance of that flow magnitude being equaled or exceeded in any given year. Stated another way, the odds are 1 in 100 that the indicated flow will be equaled or exceeded in any given year. The traditional concept of recurrence interval is directly related to the AEP. By definition, the recurrence interval (in years) is equal to one divided by the AEP. For example, the AEP of 0.01 (or 1 percent) corresponds to the 100-year flood. Table 2 lists the recurrence intervals for commonly used flood exceedance probabilities and the associated AEP, in percent.

Updated at-site flood-frequency discharges for selected AEPs (50, 20, 10, 4, 2, 1, 0.5, and 0.2 percent) were computed for USGS streamgages in the areas where flood-inundation maps were created, using the computer program PEAKFQ, version 7.2 (Flynn and others, 2006; Veilleux and others, 2014). The PEAKFQ program is based on guidelines provided

Table 2. Selected recurrence intervals and the associated annual exceedance probabilities.

\begin{tabular}{cc}
\hline $\begin{array}{c}\text { Recurrence interval } \\
\text { (years) }\end{array}$ & $\begin{array}{c}\text { Annual exceedance } \\
\text { probability (percent) }\end{array}$ \\
\hline 2 & 50 \\
5 & 20 \\
10 & 10 \\
25 & 4 \\
50 & 2 \\
100 & 1 \\
200 & 0.5 \\
500 & 0.2 \\
\hline
\end{tabular}

by the Interagency Advisory Committee on Water Data (1982) in Bulletin 17B. The October 2016 peak streamflows were included in the PEAKFQ analyses per guidance provided in USGS Office of Surface Water Technical Memorandum 2013.01 (Mason, 2012).

The updated at-site flood-frequency discharges, computed using PEAKFQ, were weighted with the regression equation estimates from Weaver and others (2009) for the streamgages with no regulation or urbanization. The at-site flood-frequency discharges for the streamgages with urbanization were weighted with the regression equations from Feaster and others (2014). The weighting method used is outlined in Bulletin 17B (Interagency Advisory Committee on Water Data, 1982, appendix 8). The weighted discharge estimates were then used to determine the AEP associated with the October 2016 peak streamflow.

\section{Estimated Magnitudes and Flood Exceedance Probabilities of Peak Streamflows}

Peak gage-height data, peak streamflow data, and the corresponding AEPs (in percent) determined from the October 2016 flood for the 24 USGS streamgages that record annual peak streamflow in the areas in and near where flood-inundation maps were created are presented in table 3 . If a streamgage is located within an area delineated by a flood-inundation map of a mapped community, then the map name and figure number associated with the streamgage is listed in table 3. Streamgage locations are shown in figure 2, and streamgages at mapped communities are also shown on respective flood-inundation maps. The estimated AEP for the October 2016 flood for each streamgage was determined using log-linear interpolation of the weighted discharge estimates following equation 1 in USGS Office of Surface Water Technical Memorandum 2013.01 (Mason, 2012). The estimated AEP provides a reasonably accurate estimate of the flood magnitude; however, uncertainty in this estimate can increase when a specific AEP is assigned to an observed flood. To show the uncertainty range, the AEP estimate is bracketed by a 90 -percent confidence interval that is likely to include the true AEP. The data listed in table 3 currently (March 2017) are considered provisional until final approval of the data. New gage-height records were set at 14 of the 24 USGS streamgages listed in table 3 . The flood-frequency statistics computed for this study are presented in table 4, which includes the length of the historical period for the streamgages that included historical flood information. The weighted flood-frequency statistics in table 4 were used to determine the AEP (in percent) associated with the October 2016 flood peaks in table 3. 
Table 3. Flood-peak gage heights, peak streamflows, and estimated annual exceedance probabilities for the October 2016 flood at selected U.S. Geological Survey streamgages in North Carolina.

[Data shown are considered provisional as of the date of this publication. Peak of record is shown in bold. Abbreviations: USGS, U.S. Geological Survey; $\mathrm{mi}^{2}$, square mile; $\mathrm{ft}^{3} / \mathrm{s}$, cubic foot per second; $\mathrm{ft}$, foot; SR, Secondary Road; NC, North Carolina; AEP, annual exceedance probability. <, less than, —, station not shown on a flood-inundation map]

\begin{tabular}{|c|c|c|c|c|c|c|c|c|c|c|c|c|c|c|}
\hline \multirow{3}{*}{$\begin{array}{c}\text { USGS } \\
\text { station } \\
\text { number } \\
\text { (fig. 2) }\end{array}$} & \multirow{3}{*}{ Station name } & \multirow{3}{*}{ Map ID } & \multirow{3}{*}{$\begin{array}{c}\text { Drainage } \\
\text { area } \\
\left(\mathrm{mi}^{2}\right)\end{array}$} & \multirow{3}{*}{$\begin{array}{l}\text { Gage } \\
\text { period of } \\
\text { record } \\
\text { (awater } \\
\text { year) }\end{array}$} & \multirow{3}{*}{ Type } & \multicolumn{3}{|c|}{$\begin{array}{l}\text { Maximum prior to October } 2016 \\
\text { flood }\end{array}$} & \multicolumn{6}{|c|}{ Maximum for October 2016 flood } \\
\hline & & & & & & \multirow{2}{*}{ Date } & \multirow{2}{*}{$\begin{array}{l}\text { Gage } \\
\text { height } \\
\text { (ft) }\end{array}$} & \multirow{2}{*}{$\begin{array}{l}\text { Discharge } \\
\text { (ft) }\end{array}$} & \multirow{2}{*}{ Date } & \multirow{2}{*}{$\begin{array}{l}\text { Gage } \\
\text { height } \\
\text { (ft) }\end{array}$} & \multirow{2}{*}{$\begin{array}{l}\text { Discharge } \\
\text { (ft) }\end{array}$} & \multirow{2}{*}{$\begin{array}{l}\text { Estimated } \\
\text { annual } \\
\text { exceedance } \\
\text { probability } \\
\text { (percent) }\end{array}$} & \multicolumn{2}{|c|}{$\begin{array}{c}\text { b90-percent } \\
\text { confidence interval }\end{array}$} \\
\hline & & & & & & & & & & & & & Lower & Upper \\
\hline 0208111310 & $\begin{array}{r}\text { Cashie River at } \\
\text { SR1257 near } \\
\text { Windsor, NC }\end{array}$ & - & 108 & $\begin{array}{l}1988- \\
\text { present }\end{array}$ & $\begin{array}{c}\text { Unregu- } \\
\text { lated }\end{array}$ & 9/16/1999 & 18.52 & 15,700 & $10 / 9 / 2016$ & 16.63 & 12,900 & ${ }^{\mathrm{b}, \mathrm{e}} 0.53$ & 1.2 & 14.9 \\
\hline 02082585 & $\begin{array}{r}\text { Tar River at NC } 97 \text { at } \\
\text { Rocky Mount, NC }\end{array}$ & - & 925 & $\begin{array}{l}\text { 1977- } \\
\text { present }\end{array}$ & ${ }^{\circ}$ Regulated & 9/17/1999 & 31.66 & 34,100 & $10 / 10 / 2016$ & 28.73 & 23,200 & b,e 2.46 & 0.9 & 11.1 \\
\hline 02083500 & $\begin{array}{l}\text { Tar River at Tarboro, } \\
\quad \text { NC }\end{array}$ & $\begin{array}{c}\text { Tar River at } \\
\text { Princeville } \\
\text { (fig. 10) }\end{array}$ & 2,183 & $\begin{array}{c}\text { 1897-1900, } \\
1906- \\
\text { present }\end{array}$ & $\begin{array}{l}\text { Unregu- } \\
\text { lated }\end{array}$ & 9/19/1999 & 41.51 & 70,600 & $10 / 12 / 2016$ & 36.29 & 41,700 & b,e 1.74 & 0.7 & 5.3 \\
\hline 02084000 & $\begin{array}{l}\text { Tar River at Green- } \\
\quad \text { ville, NC }\end{array}$ & - & 2,660 & $\begin{array}{c}\text { 1919, 1940, } \\
1997- \\
\text { present }\end{array}$ & $\begin{array}{l}\text { Unregu- } \\
\text { lated }\end{array}$ & $9 / 21 / 1999$ & 29.72 & 73,000 & $10 / 14 / 2016$ & 24.46 & 46,200 & b,e 2.84 & 4.2 & 28.3 \\
\hline 02087275 & $\begin{array}{c}\text { Crabree Creek at } \\
\text { Highway } 70 \text { at } \\
\text { Raleigh, NC }\end{array}$ & - & 97.6 & $\begin{array}{l}1996- \\
\text { present }\end{array}$ & Urbanized & $6 / 29 / 1973$ & 27.69 & 11,700 & $10 / 8 / 2016$ & 22.70 & 6,350 & b,f 17.4 & 9.0 & 35.5 \\
\hline 02088000 & $\begin{array}{l}\text { Middle Creek near } \\
\text { Clayton, NC }\end{array}$ & - & 83.5 & $\begin{array}{l}\text { 1940- } \\
\text { present }\end{array}$ & $\begin{array}{l}\text { Unregu- } \\
\text { lated }\end{array}$ & 9/6/1996 & 14.88 & 11,900 & $10 / 9 / 2016$ & 16.18 & 20,600 & $\mathrm{~b}, \mathrm{e}<0.2$ & 0.1 & 3.8 \\
\hline 02089000 & $\begin{array}{l}\text { Neuse River near } \\
\text { Goldsboro, NC }\end{array}$ & $\begin{array}{l}\text { Neuse } \\
\quad \text { River near } \\
\text { Goldsboro } \\
\text { (fig. 7) }\end{array}$ & 2,399 & $\begin{array}{c}\text { 1984-2008, } \\
2010- \\
\text { present }\end{array}$ & Regulated & 9/20/1999 & 28.85 & 38,500 & $10 / 12 / 2015$ & 29.74 & 54,300 & ${ }^{\mathrm{b}} 0.45$ & 0.2 & 8.7 \\
\hline 02089500 & $\begin{array}{l}\text { Neuse River at } \\
\text { Kinston, NC }\end{array}$ & $\begin{array}{l}\text { Neuse River } \\
\text { at Kinston } \\
\text { (fig. 8) }\end{array}$ & 2,692 & $\begin{array}{l}\text { 1984- } \\
\text { present }\end{array}$ & Regulated & $9 / 22 / 1999$ & 27.71 & 36,300 & $10 / 14 / 2016$ & 28.31 & 38,200 & ${ }^{\mathrm{b}} 0.80$ & 0.2 & 8.4 \\
\hline 02091500 & $\begin{array}{l}\text { Contentnea Creek at } \\
\text { Hookerton, } \mathrm{NC}\end{array}$ & - & 733 & $\begin{array}{l}\text { 1929- } \\
\text { present }\end{array}$ & 'Regulated & 9/18/1999 & 28.28 & 31,900 & $10 / 11 / 2016$ & 24.23 & 25,500 & b,e 0.37 & 0.4 & 5.2 \\
\hline 02102500 & $\begin{array}{l}\text { Cape Fear River at } \\
\text { Lillington, NC }\end{array}$ & - & 3,464 & $\begin{array}{l}1981- \\
\text { present }\end{array}$ & Regulated & $2 / 3 / 1973$ & 19.27 & 53,800 & $10 / 9 / 2016$ & 19.41 & 53,400 & ${ }^{\mathrm{b}} 3.10$ & 0.4 & 5.0 \\
\hline 02102908 & $\begin{array}{l}\text { Flat Creek near } \\
\text { Inverness, } \mathrm{NC}\end{array}$ & - & 7.63 & $\begin{array}{l}1969- \\
\text { present }\end{array}$ & $\begin{array}{c}\text { Unregu- } \\
\text { lated }\end{array}$ & $9 / 6 / 2008$ & 8.2 & 668 & $10 / 8 / 2016$ & 8.63 & 733 & b,e 0.60 & 0.1 & 5.9 \\
\hline
\end{tabular}


Table 3. Flood-peak gage heights, peak streamflows, and estimated annual exceedance probabilities for the October 2016 flood at selected U.S. Geological Survey streamgages in North Carolina.-Continued

[Data shown are considered provisional as of the date of this publication. Peak of record is shown in bold. Abbreviations: USGS, U.S. Geological Survey; mi² , square mile; $\mathrm{ft}^{3} / \mathrm{s}$, cubic foot per second; ft, foot; SR, Secondary Road; NC, North Carolina; AEP, annual exceedance probability. <, less than, -, station not shown on a flood-inundation map]

\begin{tabular}{|c|c|c|c|c|c|c|c|c|c|c|c|c|c|c|}
\hline \multirow{3}{*}{$\begin{array}{l}\text { USGS } \\
\text { station } \\
\text { number } \\
\text { (fig. 2) }\end{array}$} & \multirow{3}{*}{ Station name } & \multirow{3}{*}{ Map ID } & \multirow{3}{*}{$\begin{array}{c}\text { Drainage } \\
\text { area } \\
\left(\mathrm{mi}^{2}\right)\end{array}$} & \multirow{3}{*}{$\begin{array}{l}\text { Gage } \\
\text { period of } \\
\text { record } \\
\text { (awater } \\
\text { year) }\end{array}$} & \multirow{3}{*}{ Type } & \multicolumn{3}{|c|}{$\begin{array}{l}\text { Maximum prior to October } 2016 \\
\text { flood }\end{array}$} & \multicolumn{6}{|c|}{ Maximum for October 2016 flood } \\
\hline & & & & & & \multirow{2}{*}{ Date } & \multirow{2}{*}{$\begin{array}{l}\text { Gage } \\
\text { height } \\
\text { (ft) }\end{array}$} & \multirow{2}{*}{$\begin{array}{l}\text { Discharge } \\
\text { (ft) }\end{array}$} & \multirow{2}{*}{ Date } & \multirow{2}{*}{$\begin{array}{c}\text { Gage } \\
\text { height } \\
\text { (ft) }\end{array}$} & \multirow{2}{*}{$\begin{array}{l}\text { Discharge } \\
\text { (ft) }\end{array}$} & \multirow{2}{*}{$\begin{array}{l}\text { Estimated } \\
\text { annual } \\
\text { exceedance } \\
\text { probability } \\
\text { (percent) }\end{array}$} & \multicolumn{2}{|c|}{$\begin{array}{c}\text { '90-percent } \\
\text { confidence interval }\end{array}$} \\
\hline & & & & & & & & & & & & & Lower & Upper \\
\hline 02103000 & $\begin{array}{l}\text { Little River at } \\
\quad \text { Manchester, NC }\end{array}$ & - & 348 & $\begin{array}{l}\text { 1939-44, } \\
1946- \\
50, \\
2003- \\
\text { present }\end{array}$ & $\begin{array}{c}\text { Unregu- } \\
\text { lated }\end{array}$ & $9 / 29 / 2016$ & 31.18 & 9,720 & $10 / 10 / 2016$ & 32.19 & 10,600 & b,e 0.93 & 0.2 & 10.9 \\
\hline 02104220 & $\begin{array}{l}\text { Rockfish Creek at } \\
\text { Raeford, NC }\end{array}$ & - & 93.1 & $\begin{array}{l}\text { 1989-pres- } \\
\text { ent }\end{array}$ & $\begin{array}{l}\text { Unregu- } \\
\text { lated }\end{array}$ & $9 / 7 / 2008$ & 9.3 & 1,750 & $10 / 9 / 2016$ & 12.94 & 5,490 & $\mathrm{~b}, \mathrm{e}<0.2$ & 0.2 & 9.8 \\
\hline 02105500 & $\begin{array}{l}\text { Cape Fear River at } \\
\text { William O Huske } \\
\text { Lock near Tarheel, } \\
\text { NC }\end{array}$ & - & 4,852 & $\begin{array}{l}\text { 1981-95, } \\
1997- \\
2004, \\
2006- \\
12 \\
2014- \\
\text { present }\end{array}$ & Regulated & 9/8/1996 & 26.75 & (d) & $10 / 10 / 2016$ & 36.37 & 77,300 & b 0.47 & 0.2 & 8.4 \\
\hline 02105769 & $\begin{array}{l}\text { Cape Fear River } \\
\text { at Lock \#1 near } \\
\text { Kelly, NC }\end{array}$ & - & 5,255 & $\begin{array}{l}\text { 1981- } \\
\text { present }\end{array}$ & Regulated & $3 / 3 / 1979$ & 24.92 & 57,700 & $10 / 13 / 2016$ & 28.62 & 66,600 & ${ }^{\mathrm{b}} 1.37$ & 0.1 & 6.1 \\
\hline 02106500 & $\begin{array}{l}\text { Black River near } \\
\text { Tomahawk, NC }\end{array}$ & - & 676 & $\begin{array}{l}1928,1945, \\
1948, \\
1952- \\
\text { present }\end{array}$ & $\begin{array}{c}\text { Unregu- } \\
\text { lated }\end{array}$ & 9/18/1999 & 27.14 & 28,500 & $10 / 10 / 2016$ & 27.92 & 39,100 & $\mathrm{~b}, \mathrm{e}<0.2$ & 0.1 & 4.2 \\
\hline 02108000 & $\begin{array}{l}\text { Northeast Cape Fear } \\
\text { River near Chin- } \\
\text { quapin, NC }\end{array}$ & - & 599 & $\begin{array}{l}1941- \\
\text { present }\end{array}$ & $\begin{array}{l}\text { Unregu- } \\
\text { lated }\end{array}$ & 9/18/1999 & 23.51 & 30,700 & $10 / 11 / 2016$ & 19.98 & 18,200 & b,e 1.90 & 1.1 & 8.0 \\
\hline 02109500 & $\begin{array}{l}\text { Wassamaw River at } \\
\text { Freeland, NC }\end{array}$ & - & 680 & $\begin{array}{l}\text { 1940-2012, } \\
2015- \\
\text { present }\end{array}$ & $\begin{array}{l}\text { Unregu- } \\
\text { lated }\end{array}$ & 9/21/1999 & 19.3 & 31,200 & $10 / 12 / 2016$ & 19.00 & 22,000 & b,e 0.72 & 0.5 & 6.1 \\
\hline 02132320 & $\begin{array}{l}\text { Big Shoe Heel Creek } \\
\text { near Laurinburg, } \\
\text { NC }\end{array}$ & - & 83.3 & $\begin{array}{c}\text { 1988-91, } \\
1994- \\
\text { present }\end{array}$ & $\begin{array}{l}\text { Unregu- } \\
\text { lated }\end{array}$ & $9 / 10 / 2004$ & 5.52 & 1,200 & $10 / 10 / 2016$ & 6.26 & 1,480 & $\mathrm{~b}, \mathrm{e} 3.41$ & 0.2 & 10.1 \\
\hline 02133500 & $\begin{array}{l}\text { Drowning Creek near } \\
\text { Hoffman, NC }\end{array}$ & - & 183 & $\begin{array}{l}1940- \\
\text { present }\end{array}$ & $\begin{array}{c}\text { Unregu- } \\
\text { lated }\end{array}$ & $9 / 18 / 1945$ & 10.29 & 10,900 & $10 / 9 / 2016$ & 9.00 & 5,620 & $\mathrm{~b}, \mathrm{e} 2.05$ & 2.6 & 11.4 \\
\hline
\end{tabular}


Table 3. Flood-peak gage heights, peak streamflows, and estimated annual exceedance probabilities for the 0ctober 2016 flood at selected U.S. Geological Survey streamgages in North Carolina.-Continued

[Data shown are considered provisional as of the date of this publication. Peak of record is shown in bold. Abbreviations: USGS, U.S. Geological Survey; mi² , square mile; $\mathrm{ft}^{3} / \mathrm{s}$, cubic foot per second; $\mathrm{ft}$, foot; SR, Secondary Road; NC, North Carolina; AEP, annual exceedance probability. <, less than, —, station not shown on a flood-inundation map]

\begin{tabular}{|c|c|c|c|c|c|c|c|c|c|c|c|c|c|c|}
\hline \multirow{3}{*}{$\begin{array}{l}\text { USGS } \\
\text { station } \\
\text { number } \\
\text { (fig. 2) }\end{array}$} & \multirow{3}{*}{ Station name } & \multirow{3}{*}{ Map ID } & \multirow{3}{*}{$\begin{array}{c}\text { Drainage } \\
\text { area } \\
\left(\mathrm{mi}^{2}\right)\end{array}$} & \multirow{3}{*}{$\begin{array}{l}\text { Gage } \\
\text { period of } \\
\text { record } \\
\text { ( }{ }^{\mathrm{a} w a t e r} \\
\text { year) }\end{array}$} & \multirow{3}{*}{ Type } & \multicolumn{3}{|c|}{$\begin{array}{l}\text { Maximum prior to October } 2016 \\
\text { flood }\end{array}$} & \multicolumn{6}{|c|}{ Maximum for October 2016 flood } \\
\hline & & & & & & \multirow{2}{*}{ Date } & \multirow{2}{*}{$\begin{array}{c}\text { Gage } \\
\text { height } \\
\text { (ft) }\end{array}$} & \multirow{2}{*}{$\begin{array}{c}\text { Discharge } \\
\text { (ft) }\end{array}$} & \multirow{2}{*}{ Date } & \multirow{2}{*}{$\begin{array}{c}\text { Gage } \\
\text { height } \\
\text { (ft) }\end{array}$} & \multirow{2}{*}{$\begin{array}{l}\text { Discharge } \\
\text { (ft) }\end{array}$} & \multirow{2}{*}{$\begin{array}{c}\text { Estimated } \\
\text { annual } \\
\text { exceedance } \\
\text { probability } \\
\text { (percent) }\end{array}$} & \multicolumn{2}{|c|}{$\begin{array}{c}\text { b90-percent } \\
\text { confidence interval } \\
\end{array}$} \\
\hline & & & & & & & & & & & & & Lower & Upper \\
\hline 02133624 & $\begin{array}{l}\text { Lumber River near } \\
\text { Maxton, NC }\end{array}$ & - & 365 & $\begin{array}{c}1988-92 \\
1994- \\
\text { present }\end{array}$ & $\begin{array}{l}\text { Unregu- } \\
\text { lated }\end{array}$ & $3 / 22 / 1998$ & 13.52 & 3,380 & $10 / 11 / 2016$ & 15.49 & 6,790 & b,e 0.57 & 0.2 & 9.8 \\
\hline 02134170 & $\begin{array}{l}\text { Lumber River at } \\
\text { Lumberton, NC }\end{array}$ & $\begin{array}{l}\text { Lumber } \\
\text { River at } \\
\text { Lumberton } \\
\text { (fig. 4) }\end{array}$ & 708 & $\begin{array}{l}\text { 2001- } \\
\text { present }\end{array}$ & $\begin{array}{l}\text { Unregu- } \\
\text { lated }\end{array}$ & $9 / 11 / 2004$ & 18.29 & 7,420 & $10 / 10 / 2016$ & 21.87 & 14,600 & b,e 0.57 & 0.3 & 16.2 \\
\hline 02134480 & $\begin{array}{l}\text { Big Swamp near Tar } \\
\text { Heel, NC }\end{array}$ & - & 229 & $\begin{array}{l}1986- \\
\text { present }\end{array}$ & $\begin{array}{l}\text { Unregu- } \\
\text { lated }\end{array}$ & 9/17/1999 & 14.34 & 3,570 & $10 / 9 / 2016$ & 18.72 & 19,400 & $\mathrm{~b}, \mathrm{e}<0.2$ & 0.6 & 5.4 \\
\hline 02134500 & $\begin{array}{l}\text { Lumber River at } \\
\text { Boardman, } \mathrm{NC}\end{array}$ & - & 1,228 & $\begin{array}{l}1901, \\
1905- \\
06, \\
1908- \\
10 \\
1928 \\
1930- \\
\text { present }\end{array}$ & $\begin{array}{l}\text { Unregu- } \\
\text { lated }\end{array}$ & $\begin{array}{r}\text { August } \\
1928\end{array}$ & 11.80 & 25,000 & $10 / 11 / 2016$ & 14.41 & 38,200 & $\mathrm{~b}, \mathrm{e}<0.2$ & 0.2 & 2.0 \\
\hline
\end{tabular}

${ }^{a}$ Water year refers to the period October 1 to September 30 and is identified by the year in which the period ends. For example, October 1, 2001, to September 30,2002 , is water year 2002.

${ }^{b}$ Determined using methods in U.S. Geological Survey Office of Surface Water Technical Memorandum 2013.01 (Mason, 2012).

${ }^{\mathrm{c}}$ Low-flow regulation only.

dDischarge unknown.

'Determined using AEP estimates that were computed using PEAKFQ and weighted with regional regression equation estimates from Weaver and others (2009).

fDetermined using AEP estimates that were computed using PEAKFQ and weighted with regional regression equation estimates from Feaster and others (2014). 
Table 4. Flood-frequency statistics for selected U.S. Geological Survey streamgages in North Carolina.

[USGS, U.S. Geological Survey, AEP, annual exceedance probability; G, estimated from Bulletin 17B (Interagency Advisory Committee on Water Data, 1982) analysis of the streamgaging station; R, estimated from the regression equation; $\mathrm{W}$, weighted estimate; - , not applicable for regulated streamgages]

\begin{tabular}{|c|c|c|c|c|c|c|c|c|c|c|c|c|c|c|}
\hline \multirow{3}{*}{$\begin{array}{c}\text { USGS } \\
\text { station } \\
\text { number }\end{array}$} & \multirow{3}{*}{$\begin{array}{c}\text { Number } \\
\text { of annual } \\
\text { peaks }\end{array}$} & \multirow{3}{*}{$\begin{array}{c}\text { Historical } \\
\text { period of } \\
\text { record } \\
\text { (years) }\end{array}$} & \multicolumn{12}{|c|}{ Discharge, in cubic feet per second } \\
\hline & & & \multicolumn{3}{|c|}{ 50-percent chance AEP } & \multicolumn{3}{|c|}{ 20-percent chance AEP } & \multicolumn{3}{|c|}{ 10-percent chance AEP } & \multicolumn{3}{|c|}{ 4-percent chance AEP } \\
\hline & & & G & $\mathbf{R}$ & $\mathbf{w}$ & G & $\mathbf{R}$ & $\mathbf{w}$ & G & $\mathbf{R}$ & $\mathbf{w}$ & G & $\mathbf{R}$ & $\mathbf{w}$ \\
\hline 0208111310 & 30 & none & 1,920 & 1,260 & 1,730 & 4,570 & 2,320 & 3,700 & 7,250 & 3,120 & 5,330 & 12,000 & 4,190 & 7,560 \\
\hline 02082585 & 41 & none & 7,970 & 10,900 & 8,120 & 12,200 & 17,700 & 12,500 & 15,300 & 22,600 & 15,900 & 19,400 & 28,500 & 20,300 \\
\hline 02083500 & 116 & 121 & 13,800 & 16,000 & 13,800 & 20,800 & 26,000 & 20,900 & 26,100 & 33,100 & 26,300 & 33,500 & 41,800 & 33,900 \\
\hline 02084000 & 22 & 130 & 15,700 & 16,300 & 15,800 & 25,000 & 26,800 & 25,200 & 32,000 & 34,100 & 32,200 & 41,600 & 43,200 & 41,800 \\
\hline 02087275 & 21 & none & 3,800 & 4,020 & 3,820 & 5,920 & 6,200 & 5,960 & 7,540 & 7,690 & 7,580 & 9,840 & 9,590 & 9,760 \\
\hline 02088000 & 78 & none & 1,520 & 1,820 & 1,540 & 3,010 & 3,210 & 3,030 & 4,410 & 4,230 & 4,380 & 6,730 & 5,550 & 6,480 \\
\hline 02089000 & 34 & 89 & 10,100 & - & - & 15,900 & - & - & 20,700 & - & - & 28,300 & - & - \\
\hline 02089500 & 34 & 99 & 10,300 & - & - & 15,600 & - & - & 19,700 & - & - & 25,600 & - & - \\
\hline 02091500 & 89 & 94 & 4,120 & 5,280 & 4,160 & 6,940 & 9,160 & 7,050 & 9,250 & 12,000 & 9,420 & 12,700 & 15,600 & 13,000 \\
\hline 02102500 & 36 & none & 26,200 & - & - & 36,400 & - & - & 43,000 & - & - & 50,900 & - & - \\
\hline 02102908 & 49 & none & 122 & 119 & 122 & 226 & 202 & 223 & 316 & 264 & 307 & 458 & 345 & 431 \\
\hline 02103000 & 26 & none & 2,900 & 2,180 & 2,810 & 4,800 & 3,500 & 4,580 & 6,250 & 4,500 & 5,890 & 8,310 & 5,800 & 7,660 \\
\hline 02104220 & 29 & none & 637 & 809 & 657 & 1,140 & 1,330 & 1,170 & 1,580 & 1,720 & 1,610 & 2,260 & 2,230 & 2,250 \\
\hline 02105500 & 34 & 37 & 27,800 & - & - & 37,300 & - & - & 44,100 & - & - & 53,200 & - & - \\
\hline 02105769 & 37 & none & 24,300 & - & - & 34,500 & - & - & 42,100 & - & - & 52,500 & - & - \\
\hline 02106500 & 66 & 90 & 4,440 & 4,140 & 4,420 & 8,070 & 7,320 & 8,000 & 11,300 & 9,680 & 11,100 & 16,300 & 12,700 & 15,700 \\
\hline 02108000 & 77 & 110 & 5,140 & 3,820 & 5,080 & 8,500 & 6,780 & 8,390 & 11,200 & 8,990 & 11,000 & 15,100 & 11,800 & 14,700 \\
\hline 02109500 & 76 & 78 & 3,910 & 4,150 & 3,920 & 6,980 & 7,340 & 7,010 & 9,530 & 9,720 & 9,550 & 13,300 & 12,800 & 13,200 \\
\hline 02132320 & 28 & 30 & 481 & 926 & 509 & 750 & 1,640 & 819 & 944 & 2,180 & 1,060 & 1,200 & 2,890 & 1,400 \\
\hline 02133500 & 78 & none & 1,310 & 1,330 & 1,310 & 2,330 & 2,150 & 2,310 & 3,240 & 2,780 & 3,190 & 4,720 & 3,590 & 4,520 \\
\hline 02133624 & 29 & 30 & 1,780 & 2,300 & 1,810 & 2,680 & 3,740 & 2,760 & 3,320 & 4,830 & 3,470 & 4,190 & 6,240 & 4,440 \\
\hline 02134170 & 17 & 122 & 2,770 & 4,030 & 2,960 & 4,680 & 6,780 & 5,020 & 6,170 & 8,850 & 6,620 & 8,280 & 11,500 & 8,870 \\
\hline 02134480 & 32 & none & 1,400 & 2,050 & 1,490 & 2,790 & 3,710 & 2,960 & 4,070 & 4,970 & 4,300 & 6,200 & 6,610 & 6,340 \\
\hline 02134500 & 88 & 122 & 4,960 & 5,970 & 4,990 & 8,180 & 10,100 & 8,250 & 10,700 & 13,300 & 10,900 & 14,500 & 17,200 & 14,700 \\
\hline
\end{tabular}


Table 4. Flood-frequency statistics for selected U.S. Geological Survey streamgages in North Carolina._Continued

[USGS, U.S. Geological Survey, AEP, annual exceedance probability; G, estimated from Bulletin 17B (Interagency Advisory Committee on Water Data, 1982) analysis of the streamgaging station; R, estimated from the regression equation; $\mathrm{W}$, weighted estimate; —, not applicable for regulated streamgages]

\begin{tabular}{|c|c|c|c|c|c|c|c|c|c|c|c|c|c|c|}
\hline \multirow{3}{*}{$\begin{array}{l}\text { USGS } \\
\text { station } \\
\text { number }\end{array}$} & \multirow{3}{*}{$\begin{array}{c}\text { Number } \\
\text { of annual } \\
\text { peaks }\end{array}$} & \multirow{3}{*}{$\begin{array}{l}\text { Historical } \\
\text { period of } \\
\text { record } \\
\text { (years) }\end{array}$} & \multicolumn{12}{|c|}{ Discharge, in cubic feet per second } \\
\hline & & & \multicolumn{3}{|c|}{ 2-percent chance AEP } & \multicolumn{3}{|c|}{ 1-percent chance AEP } & \multicolumn{3}{|c|}{ 0.5-percent chance AEP } & \multicolumn{3}{|c|}{ 0.2-percent chance AEP } \\
\hline & & & $\mathbf{G}$ & $\mathbf{R}$ & $\mathbf{w}$ & $\mathbf{G}$ & $\mathbf{R}$ & $\mathbf{w}$ & G & $\mathbf{R}$ & $\mathbf{w}$ & G & $\mathbf{R}$ & $\mathbf{w}$ \\
\hline 0208111310 & 30 & none & 16,600 & 5,130 & 9,380 & 22,300 & 6,140 & 11,300 & 29,300 & 7,040 & 13,100 & 41,000 & 8,420 & 15,700 \\
\hline 02082585 & 41 & none & 22,700 & 33,800 & 24,100 & 26,100 & 38,500 & 27,900 & 29,700 & 43,000 & 31,900 & 34,700 & 49,800 & 37,600 \\
\hline 02083500 & 116 & 121 & 39,500 & 49,500 & 40,100 & 45,900 & 56,600 & 46,700 & 52,800 & 63,100 & 53,700 & 62,700 & 73,000 & 63,900 \\
\hline 02084000 & 22 & 130 & 49,400 & 51,300 & 49,700 & 57,700 & 58,800 & 57,900 & 66,500 & 65,700 & 66,300 & 79,100 & 76,200 & 78,400 \\
\hline 02087275 & 21 & none & 11,700 & 11,000 & 11,400 & 13,800 & 12,300 & 13,100 & 16,000 & 13,800 & 14,900 & 19,300 & 15,600 & 17,200 \\
\hline 02088000 & 78 & none & 8,940 & 6,710 & 8,350 & 11,600 & 7,840 & 10,400 & 14,800 & 8,890 & 12,600 & 20,100 & 10,500 & 15,800 \\
\hline 02089000 & 34 & 89 & 35,000 & - & - & 42,900 & - & - & 52,000 & - & - & 66,400 & - & - \\
\hline 02089500 & 34 & 99 & 30,500 & - & - & 35,900 & - & - & 41,800 & - & - & 50,600 & - & - \\
\hline 02091500 & 89 & 94 & 15,700 & 18,800 & 16,100 & 19,000 & 22,100 & 19,500 & 22,800 & 25,000 & 23,200 & 28,600 & 29,400 & 28,700 \\
\hline 02102500 & 36 & none & 56,600 & - & - & 62,100 & - & - & 67,500 & - & - & 74,600 & - & - \\
\hline 02102908 & 49 & none & 586 & 404 & 533 & 734 & 462 & 640 & 904 & 531 & 757 & 1,170 & 608 & 914 \\
\hline 02103000 & 26 & none & 9,990 & 6,770 & 9,020 & 11,800 & 7,680 & 10,400 & 13,700 & 8,820 & 11,900 & 16,500 & 10,100 & 13,800 \\
\hline 02104220 & 29 & none & 2,870 & 2,610 & 2,780 & 3,580 & 2,980 & 3,340 & 4,400 & 3,420 & 3,960 & 5,690 & 3,910 & 4,790 \\
\hline 02105500 & 34 & 37 & 60,500 & - & - & 68,200 & - & - & 76,300 & - & - & 87,900 & - & - \\
\hline 02105769 & 37 & none & 61,000 & - & - & 70,100 & - & - & 79,800 & - & - & 93,800 & - & - \\
\hline 02106500 & 66 & 90 & 20,900 & 15,400 & 19,700 & 26,300 & 18,200 & 24,100 & 32,500 & 20,700 & 28,800 & 42,500 & 24,500 & 35,700 \\
\hline 02108000 & 77 & 110 & 18,500 & 14,300 & 17,900 & 22,200 & 17,000 & 21,300 & 26,300 & 19,300 & 24,900 & 32,400 & 22,900 & 30,200 \\
\hline 02109500 & 76 & 78 & 16,700 & 15,500 & 16,500 & 20,400 & 18,300 & 20,000 & 24,500 & 20,800 & 23,600 & 30,800 & 24,600 & 29,100 \\
\hline 02132320 & 28 & 30 & 1,410 & 3,480 & 1,690 & 1,620 & 4,090 & 2,010 & 1,840 & 4,690 & 2,340 & 2,150 & 5,530 & 2,830 \\
\hline 02133500 & 78 & none & 6,100 & 4,200 & 5,650 & 7,750 & 4,770 & 6,870 & 9,730 & 5,470 & 8,260 & 12,900 & 6,250 & 10,100 \\
\hline 02133624 & 29 & 30 & 4,860 & 7,320 & 5,220 & 5,560 & 8,340 & 6,030 & 6,290 & 9,570 & 6,920 & 7,320 & 11,000 & 8,110 \\
\hline 02134170 & 17 & 122 & 10,000 & 13,700 & 10,700 & 11,900 & 15,900 & 12,800 & 13,900 & 18,100 & 14,900 & 16,900 & 21,100 & 18,000 \\
\hline 02134480 & 32 & none & 8,210 & 8,050 & 8,150 & 10,600 & 9,590 & 10,200 & 13,500 & 11,000 & 12,300 & 18,200 & 13,100 & 15,400 \\
\hline 02134500 & 88 & 122 & 17,600 & 20,600 & 17,900 & 21,100 & 24,000 & 21,500 & 25,000 & 27,300 & 25,300 & 30,700 & 31,900 & 30,900 \\
\hline
\end{tabular}




\section{Flood-Inundation Maps}

Seven flood-inundation maps were created for heavily flooded communities in North Carolina (figs. 4 to 10). Each map presents the areal extent of the flood waters. Information about the HWMs used to create the inundation maps, as well as digital datasets of the inundation area, modeling boundary, and waterdepth rasters, are available for download at Watson and Musser, 2017. Details pertinent to the creation of specific flood-inundation maps are described in the following sections. All elevations are referenced to NAVD 88 unless otherwise noted.

\section{Lumber River at Lumberton}

The Lumber River generally flows southeast through southcentral North Carolina and then into South Carolina. The extent of the inundation map around Lumberton in Robeson County is an 11.5-mi reach of the Lumber River and a 2.3-mi reach of Little Jacob Swamp, which flows into a 3.1-mi reach of Jacob Branch. A total of 27 USGS HWMs were documented and surveyed in the Lumberton area, and 24 were used to create the inundation map. Water-surface elevations at the HWMs ranged from $109.4 \mathrm{ft}$ at NCROB18753 to $125.5 \mathrm{ft}$ at NCROB18727. Elevation data from the USGS streamgaging station, Lumber River at Lumberton, NC (02134170), were also used in the creation of the inundation map. The streamgaging station recorded a peak flow of $14,600 \mathrm{ft}^{3} / \mathrm{s}$, a peak stage of $21.87 \mathrm{ft}$ gage datum, and a water-surface elevation of $119.26 \mathrm{ft}$ on October 10, 2016. Eleven cross sections were created and used with the HWMs to generate a flood-elevation surface. Precipitation ranged from about 4.6 to 16.1 inches in the Lumber River Basin during October 7-9 (fig. 3). The aerial extent of flood inundation for this location is shown in figure 4 .

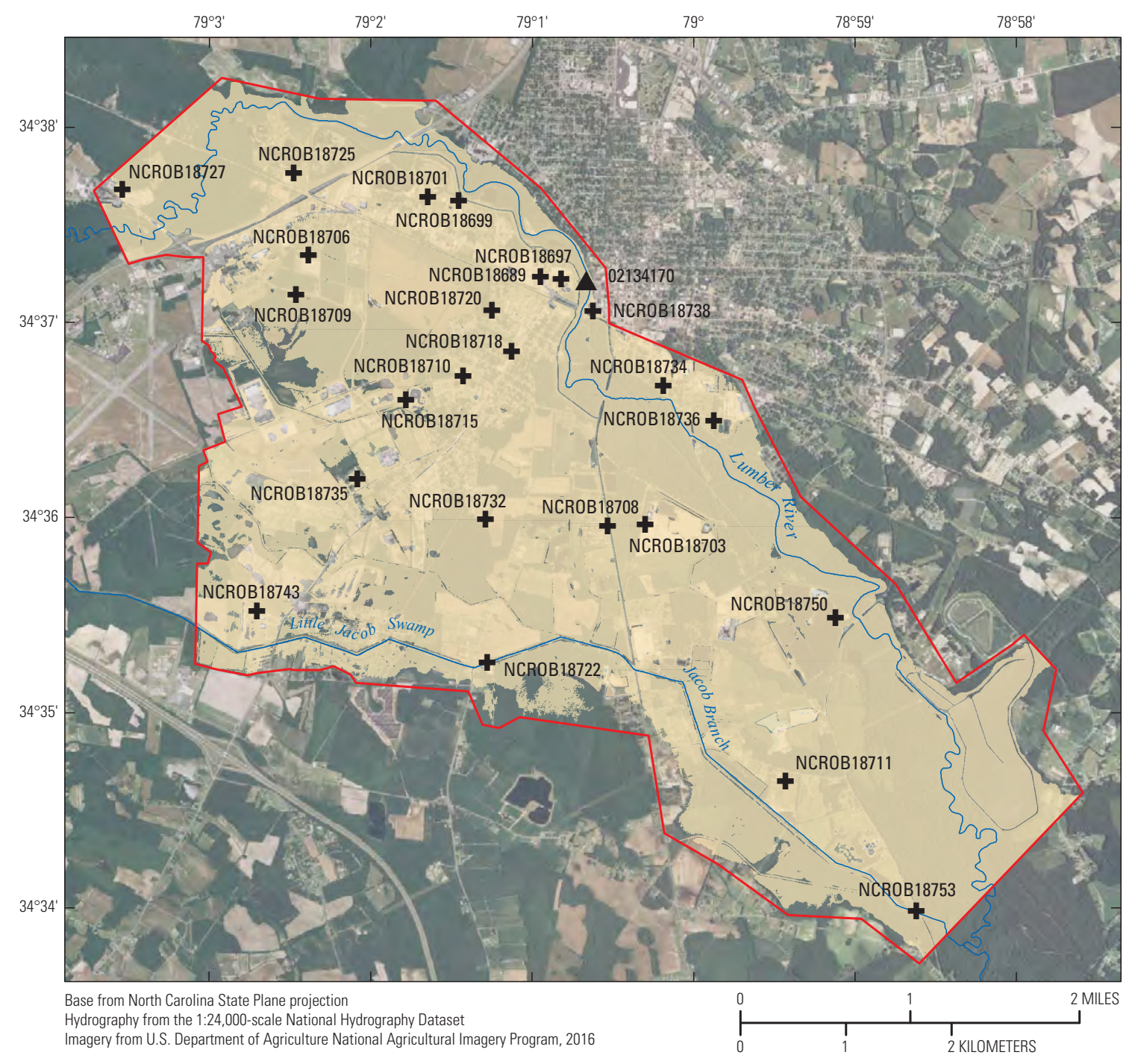

Figure 4. Flood-inundation map, Lumber River at Lumberton, North Carolina, October 2016. 


\section{Lumber River at Fair Bluff}

The extent of the inundation map around Fair Bluff is a 3.5-mi reach of the Lumber River along the Robeson and Columbus County line. A total of six USGS HWMs were documented and surveyed along the Lumber River, and five were used to create the inundation map. Water-surface elevations at the HWMs ranged from $65.1 \mathrm{ft}$ at NCCOL18749 to $67.8 \mathrm{ft}$ at NCCOL18768. Five cross sections were created and used to generate a flood-elevation surface. Because the Lumber River flood plain is approximately $3.5 \mathrm{mi}$ wide and all of the HWMs are located on one side of the river, the inundation map does not extend to the far edge of the flood plain. The aerial extent of flood inundation for this location is shown in figure 5 .

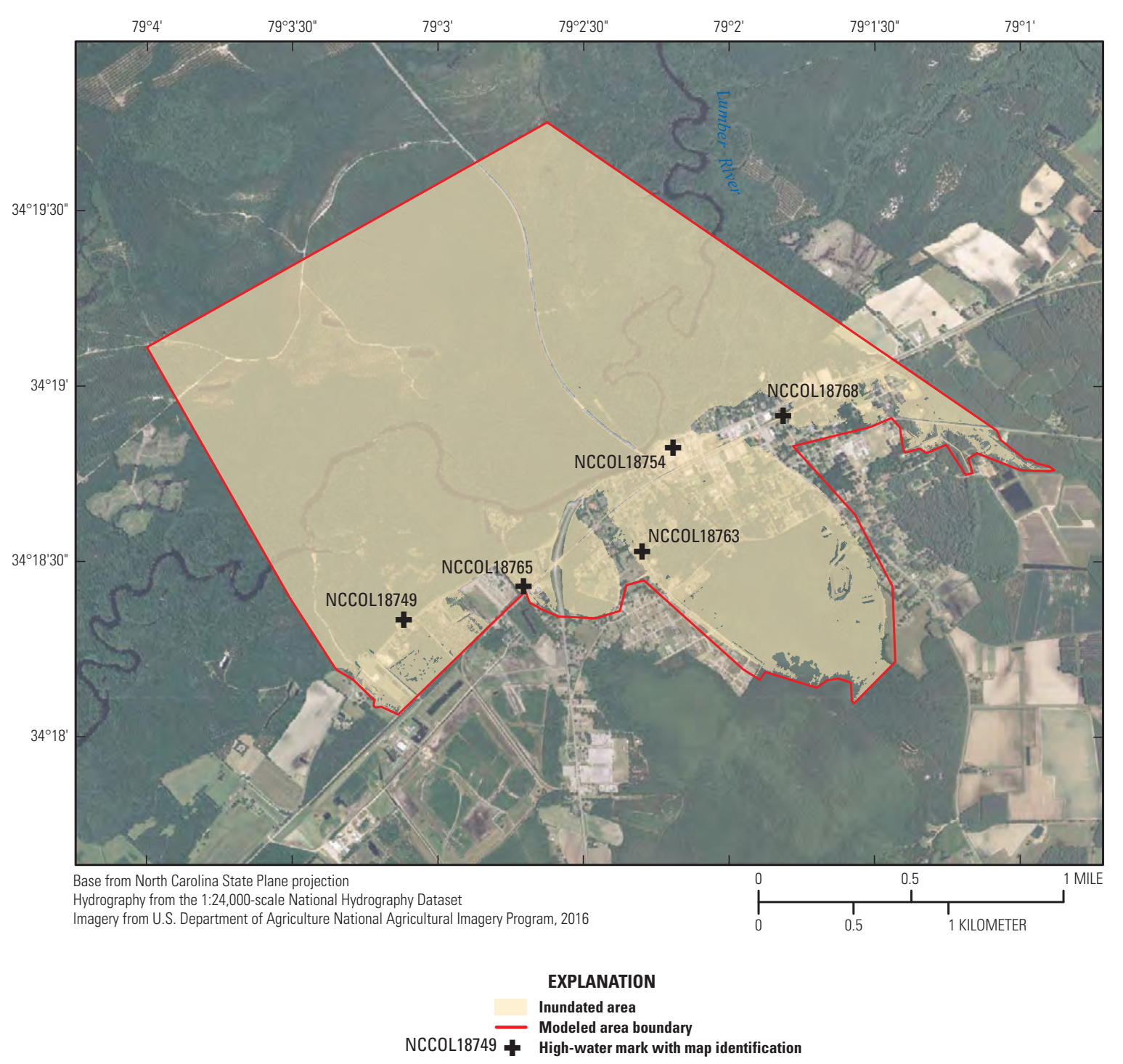

Figure 5. Flood-inundation map, Lumber River at Fair Bluff, North Carolina, October 2016. 


\section{Neuse River at Smithfield}

The Neuse River generally flows southeast through central and eastern North Carolina. The extent of the inundation map around Smithfield in Johnston County is a 4.8-mi reach of the Neuse River, a 2.6-mi reach of Swift Creek, and a 2.4-mi reach of Middle Creek. Additionally, a 2.6-mi section of Holts Lake on Black Creek south of Smithfield was mapped. A total of 10 USGS HWMs were documentedseven on the Neuse River, one on Swift Creek, one on Middle Creek, and one on Holts Lake. Water-surface elevations at the HWMs ranged from $122.9 \mathrm{ft}$ at NCJOH18782 to $128.5 \mathrm{ft}$ on the Neuse River at NCJOH18797. The peak HWM on Swift Creek was $127.2 \mathrm{ft}$ at NCJOH18798, and the peak HWM

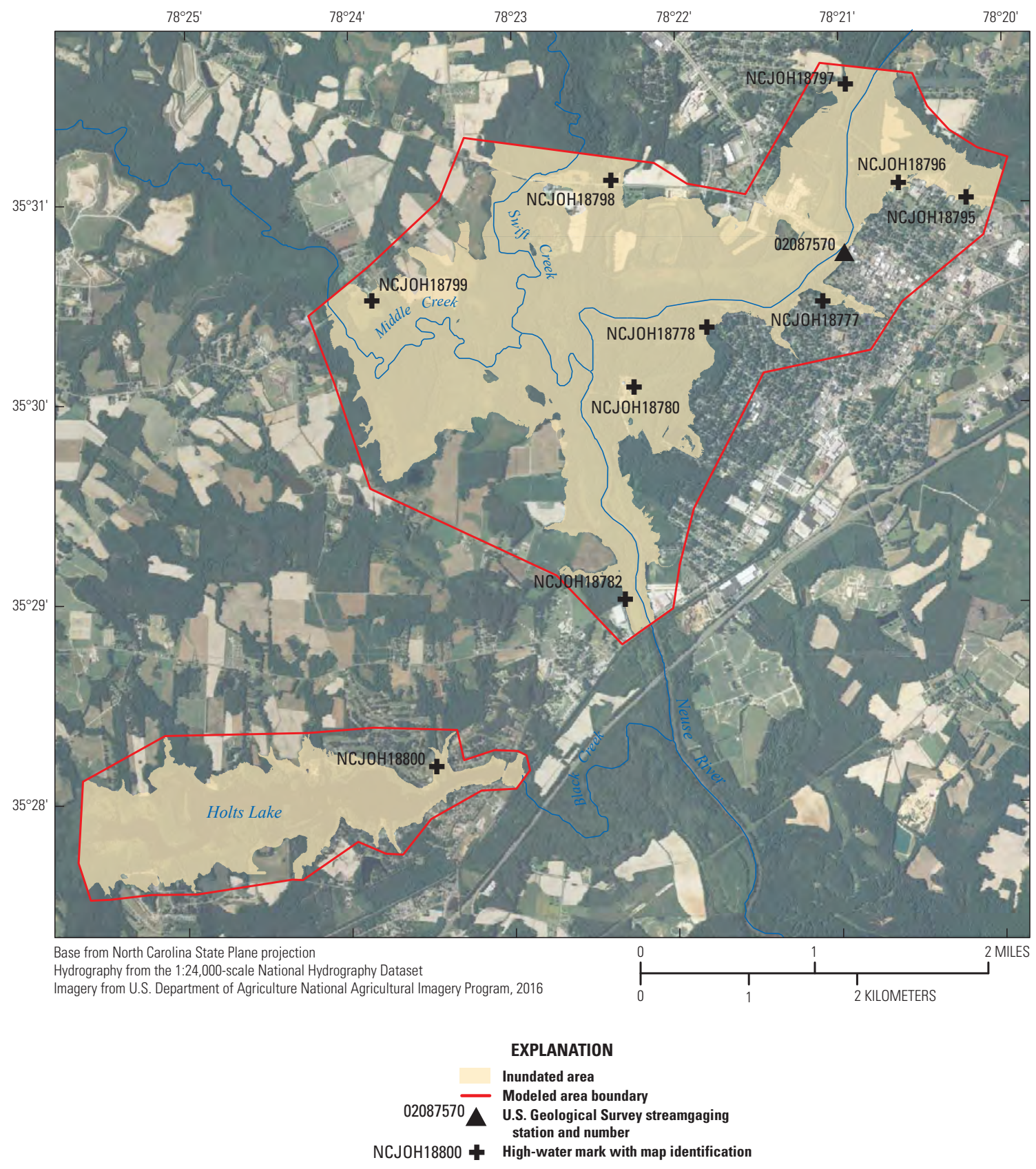

Figure 6. Flood-inundation map, Neuse River at Smithfield, North Carolina, October 2016. 
on Middle Creek was $127.0 \mathrm{ft}$ at NCJOH18799. The USGS stage only streamgaging station Neuse River at Smithfield, NC (02087570), recorded a peak stage of $29.09 \mathrm{ft}$ gage datum and a water-surface elevation of $128.35 \mathrm{ft}$ National Geodetic Vertical Datum of 1929 (NGVD 29) on October 9, 2016. The water-surface elevation was converted to $127.40 \mathrm{ft}$ NAVD 88 using National Geodetic Survey VERTCON (National Geodetic Survey, 2017). This elevation was also used in the creation of the inundation map. Because the streamgage is stage only, flood-frequency computations could not be made at this location, and, therefore, the streamgage is not included in figures 2 and 3, and tables 3 and 4 . Ten cross sections were used along the Neuse River, Swift Creek, and Middle Creek to generate the flood-elevation surface. In the area around Holts Lake, a constant surface of $122.3 \mathrm{ft}$, which was based on the HWM NCJOH18800, was used to determine the flood extent. Precipitation ranged from about 4.1 to 14.7 inches in the Neuse River Basin during October 7-9 (fig. 3). The aerial extent of flood inundation for this location is shown in figure 6.

\section{Neuse River near Goldsboro}

The Neuse River generally flows east through Goldsboro in Wayne County, and the Little River and Stoney Creek flow south into the Neuse River near Goldsboro. The extent of the inundation map around Goldsboro is a 20.8-mi reach of the Neuse River, an 11.8-mi reach of the Little River, and a 6.3-mi reach of Stoney Creek. A total of 22 USGS HWMs were documented and surveyed, and 20 were used to create the inundation map. Water-surface elevations at the HWMs on the Neuse River ranged from $69.2 \mathrm{ft}$ at NCWAY 18794 to $76.5 \mathrm{ft}$ at NCWAY18756. The water-surface elevation on the Little River was $91.2 \mathrm{ft}$ at NCWAY18783 and on Stoney Creek was 95.0 at NCWAY18790. Elevation data from the USGS streamgaging station Neuse River near Goldsboro, NC (02089000), were also used in the creation of the inundation map. The streamgaging station recorded a peak flow of $54,300 \mathrm{ft}^{3} / \mathrm{s}$, a peak stage of $29.74 \mathrm{ft}$ gage datum, and a water-surface elevation of $72.69 \mathrm{ft}$ NGVD 29 on October 12,2016 . The water-surface elevation was converted to $71.67 \mathrm{ft}$ NAVD 88 using VERTCON (National Geodetic Survey, 2017). Seventeen cross sections were create-eight on the Neuse River, four on the Little River, and five on Stoney Creek - to generate the flood-elevation surface. The aerial extent of flood inundation for this location is shown in figure 7. 


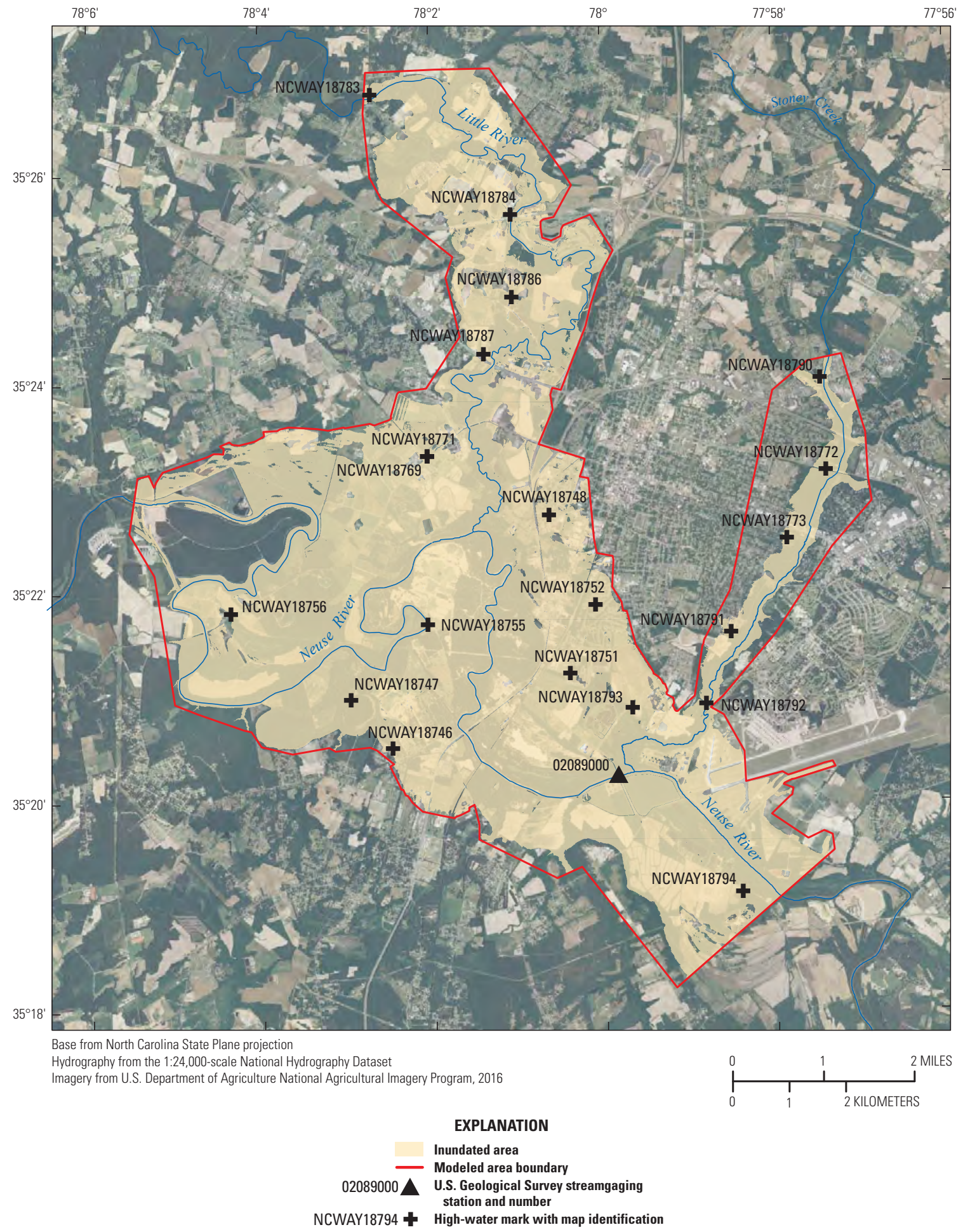

Figure 7. Flood-inundation map, Neuse River near Goldsboro, North Carolina, October 2016. 


\section{Neuse River at Kinston}

The extent of the inundation map around Kinston in Lenoir County is a 9.3-mi reach of the Neuse River and a 5.0-mi reach of Southwest Creek. A total of 21 NCEM HWMs were documented and surveyed along the Neuse River and Southwest Creek, and 10 were used to create the inundation map. The elevation of water at the HWMs ranged from $32.9 \mathrm{ft}$ at HWM 6 to $46.0 \mathrm{ft}$ at HWM 8. Elevation data from the USGS streamgaging station Neuse River at Kinston, NC
(02089500), were also used in the creation of the inundation map. The streamgaging station recorded a peak flow of $38,200 \mathrm{ft}^{3} / \mathrm{s}$, a peak stage of $28.31 \mathrm{ft}$ gage datum, and a watersurface elevation of $39.21 \mathrm{ft}$ NGVD 29 on October 14, 2016. The water-surface elevation was converted to $38.05 \mathrm{ft}$ NAVD 88 using VERTCON (National Geodetic Survey, 2017). Eight cross sections were created - six on the Neuse River and two on Southwest Creek - to generate the flood-elevation surface. The aerial extent of flood inundation for this location is shown in figure 8.

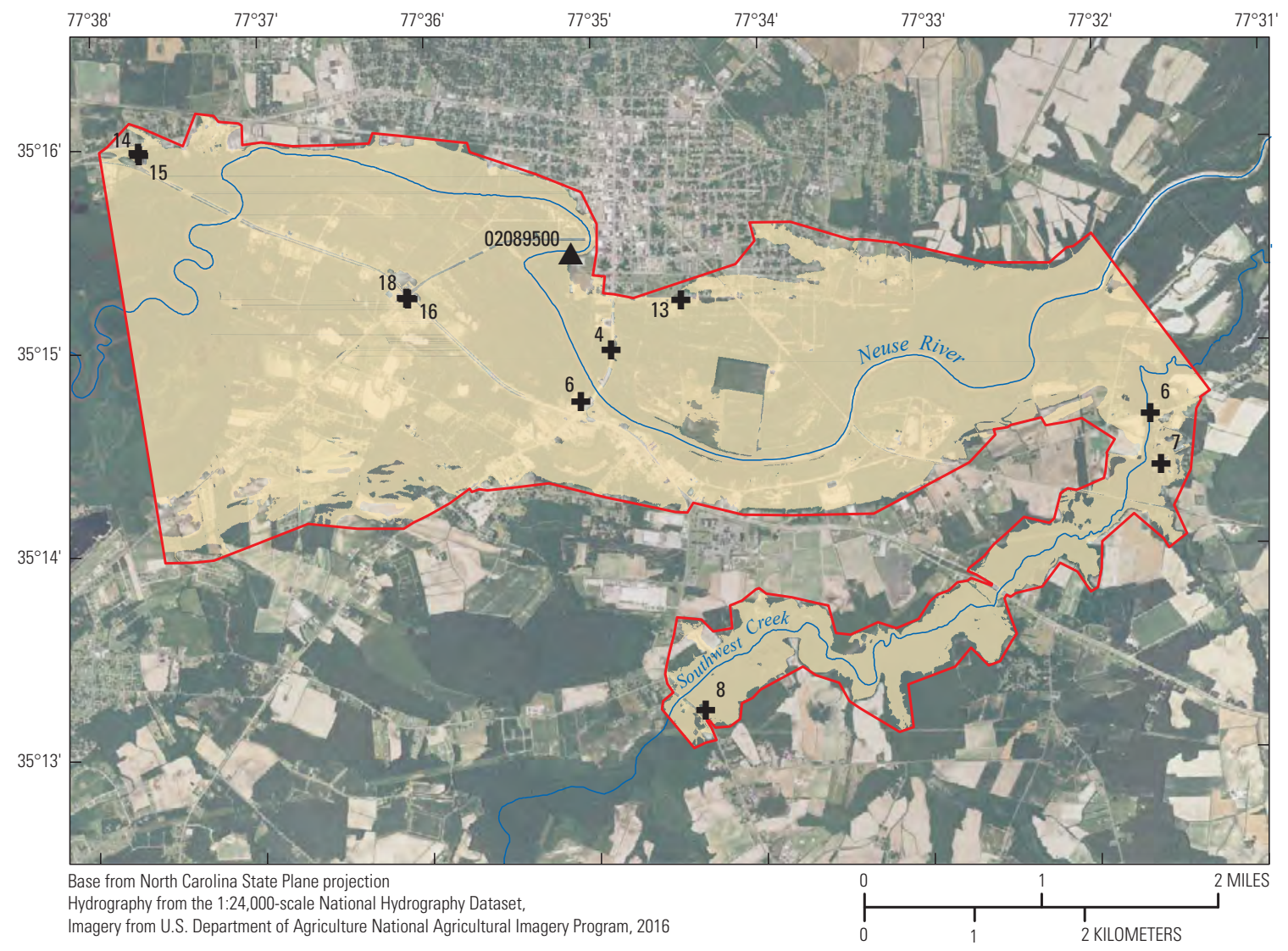

EXPLANATION

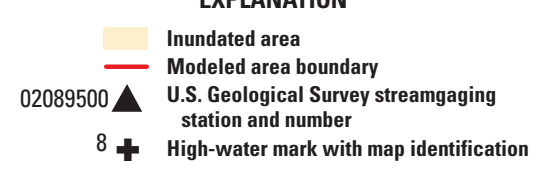

Figure 8. Flood-inundation map, Neuse River at Kinston, North Carolina, October 2016. 


\section{Rockfish Creek at Hope Mills}

Little Rockfish Creek and Rockfish Creek flow east to the Cape Fear River in southeast North Carolina. The extent of the inundation map is a 3.2-mi reach of Little Rockfish Creek and a 1.5-mi reach of Rockfish Creek through Hope Mills in Cumberland County. A total of nine HWMs were documented and surveyed along the Little Rockfish Creek and Rockfish Creek, and seven were used to create the inundation map. Water-surface elevations at the HWMs ranged from $100.7 \mathrm{ft}$ at NCCUM18714 on Rockfish Creek to $111.3 \mathrm{ft}$ at NCCUM18726 on Little Rockfish Creek. Seven cross sections were created - three on Rockfish Creek and four on Little Rockfish Creek - to generate the flood-elevation surface. Precipitation ranged from about 6.9 to 13.8 inches in the Rockfish Creek Basin during October 7-9 (fig. 3). The aerial extent of flood inundation for this location is shown in figure 9.

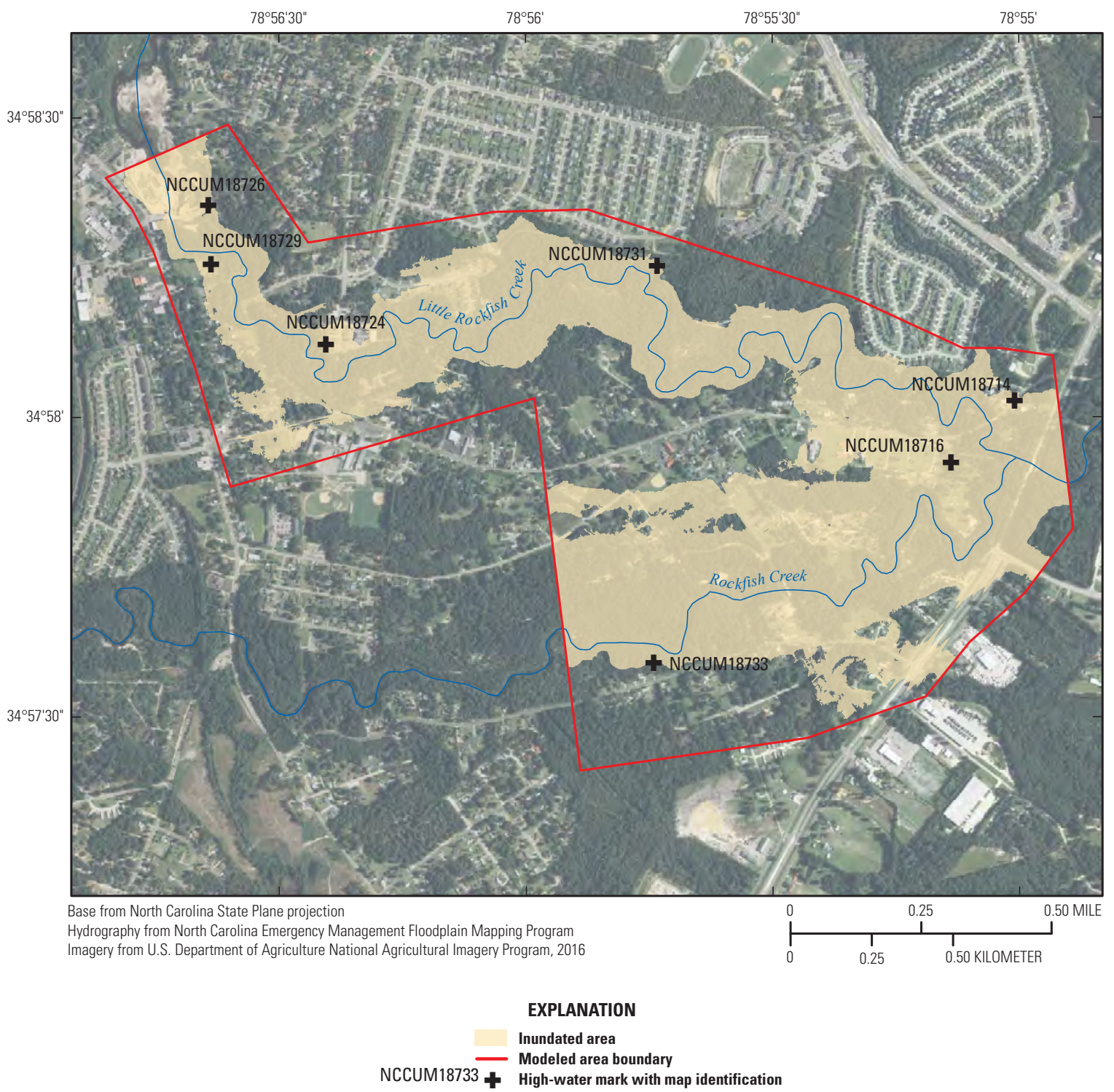

Figure 9. Flood-inundation map, Rockfish Creek at Hope Mills, North Carolina, October 2016. 


\section{Tar River at Princeville}

The Tar River generally flows southeast through central and eastern North Carolina. The Tar River flows between the towns of Tarboro, to the northwest, and Princeville, to the southeast. A levee is located along the Princeville side of the Tar River. A total of 12 HWMs used to create the inundation map were documented and surveyed by the North Carolina Geodetic Survey (NCGS) in the vicinity of the Tar River on the town side of the levee within the town of Princeville during May 2017. The U.S. Army Corps of Engineers (USACE) had previously identified HWMs, which were surveyed by NCEM along the Tar River and around Prince-ville; however, it was subsequently determined that these marks did not represent peak water elevations. These water marks were used to monitor the differences in water elevation on either side of the levee during the flood (Wesley Brown, U.S. Army Corps of Engineers, written commun., April 4, 2017). Additional water marks were documented by the USACE but were not surveyed. Water-surface elevations at the NCGS-surveyed HWMs ranged from $44.27 \mathrm{ft}$ at water marks FD 1 and RR 1 to $44.57 \mathrm{ft}$ at water mark SS 1 over a reach of 2.1 miles. Elevation data from the USGS streamgaging station Tar River at Tarboro, NC (02083500), recorded a peak flow of $42,500 \mathrm{ft}^{3} / \mathrm{s}$, a peak stage of $36.29 \mathrm{ft}$ gage datum, and a water-surface elevation of $45.61 \mathrm{ft}$ on October 12, 2016. Precipitation ranged from about 14.4 to 13.2 inches in the Tar River Basin during October 7-9 (fig. 3). The aerial extent of flood inundation within Princeville is shown in figure 10. 


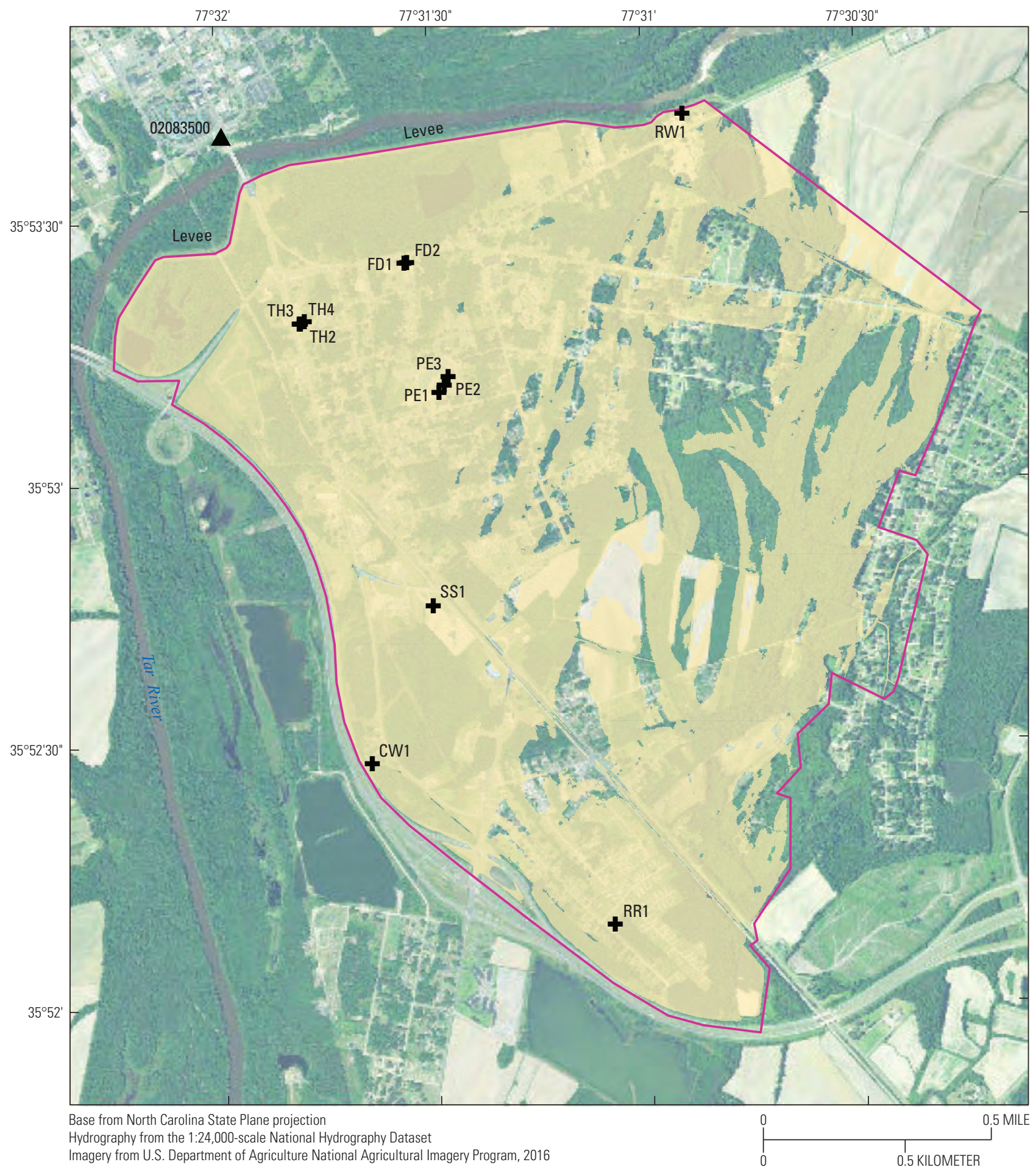

EXPLANATION

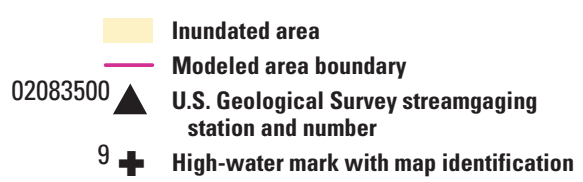

Figure 10. Flood-inundation map, Tar River at Princeville, North Carolina, October 2016. 


\section{Summary}

In October 2016, rainfall from Hurricane Matthew caused flooding on numerous streams and rivers in central and eastern North Carolina. Rainfall totals of 3 inches to more than 15 inches were widespread throughout the area. More than 600 roads were closed, and nearly 99,000 structures were affected by floodwaters. The U.S. Geological Survey (USGS) documented 267 high-water marks (HWM) during the period October 9-24, 2016. Of these, 254 HWMs were surveyed to elevation above the North American Vertical Datum of 1988. In addition, North Carolina Emergency Management identified and surveyed 353 HWMs, and the North Carolina Geodetic Survey identified and surveyed 12 HWMs in Princeville. The HWMs were used to create seven maps showing the areas of inundation in seven heavily flooded communities. Additionally, the depth of the water in the mapped inundated areas was calculated, and a water-depth raster was created. The flood-inundation maps, water-depth rasters, and mapping boundaries are available for download. Flood-peak gage heights, peak streamflows, and estimated annual exceedance probabilities were calculated for 24 USGS streamgages located within or near the areas that were mapped. Additional information, including a download portal for HWM information, is available from the USGS Hurricane Matthew web page (https://water.usgs.gov/floods/events/2016/matthew/, accessed November 29, 2016).

\section{References Cited}

Cooke, C.W., 1936, Geology of the Coastal Plain of South Carolina: U.S. Geological Survey Bulletin 867, 196 p.

Feaster, T.D., Gotvald, A.J., and Weaver, J.C., 2014, Methods for estimating the magnitude and frequency of floods for urban and small, rural streams in Georgia, South Carolina, and North Carolina, 2011 (ver. 1.1, March 2014): U.S. Geological Survey Scientific Investigations Report 2014-5030, 104 p., https://dx.doi.org/10.3133/sir20145030.

Flynn, K.M., Kirby, W.H., and Hummel, P.R., 2006, User's manual for program PeakFQ annual flood-frequency analysis using Bulletin 17B guidelines: U.S. Geological Survey Techniques and Methods, book 4, chap. B4, 42 p.

Giese, G.L., and Mason, R.R., Jr., 1993, Low-flow characteristics of streams in North Carolina: U.S. Geological Survey Water-Supply Paper 2403, 29 p. +2 pl. (Also available at https://pubs.er.usgs.gov/publication/wsp2403.)

Interagency Advisory Committee on Water Data, 1982, Guidelines for determining flood flow frequency, Bulletin 17B of the Hydrology Subcommittee: U.S. Geological Survey, Office of Water Data Coordination [variously paged].
Koenig, T.A., Bruce, J.L., O’Connor, J.E., McGee, B.D., Holmes, R.R., Jr., Hollins, Ryan, Forbes, B.T., Kohn, M.S., Schellekens, M.F., Martin, Z.W., and Peppler, M.C., 2016, Identifying and preserving high-water mark data: U.S. Geological Survey Techniques and Methods, book 3, chap. A24, 47 p. (Also available at https://dx.doi. org/10.3133/tm3A24.)

Langbein, W.B., and Iseri, K.T., 1960, General introduction and hydrologic definitions, Manual of hydrology —Part 1. General surface-water techniques: U.S. Geological Survey Water-Supply Paper 1541-A, 29 p.

Mason, R.R., Jr., 2012, Computation of annual exceedance probability (AEP) for characterization of observed flood peaks: U.S. Geological Survey Office of Surface Water Technical Memorandum 2013.01, accessed March 16, 2017, at https://water.usgs.gov/admin/memo/SW/sw13.01.pdf.

Musser, J.W., Watson, K.M., Painter, J.A., and Gotvald, A.J., 2016, Flood-inundation maps of selected areas affected by the flood of October 2015 in central and coastal South Carolina: U.S. Geological Survey Open-File Report 2016-1019, 81 p., accessed January 23, 2017, at https://dx.doi.org/10.3133/ofr20161019.

National Geodetic Survey, VERTCON—North American Vertical Datum conversion: National Oceanic and Atmospheric Administration, National Geodetic Survey web page, accessed January 15, 2017, at https://www.ngs. noaa.gov/TOOLS/Vertcon/vertcon.html.

National Weather Service, 2017, Advanced hydrologic prediction service: National Oceanic and Atmospheric Administration, National Weather Service web page, accessed January 25, 2017, at http://water.weather.gov/ precip/download.php.

North Carolina Floodplain Mapping Program, 2016, North Carolina's spatial data download: North Carolina Emergency Management web page, accessed December 5, 2016, at https://rmp.nc.gov/sdd/.

Omernik, J.M., 1987, Ecoregions of the conterminous United States: Annals of the Association of American Geographers, v. 77 , no. 1, p. 118-125, map scale $1: 7,500,000$.

Southeast Regional Climate Center, 2016, Multi-sensor precipitation estimates, October 4-10, 2016, Hurricane Matthew storm total rainfall: Southeast Regional Climate Center web page, accessed November 10, 2016, at http://www.sercc.com/Hurricane_Matthew_MPE_Map.png.

State Climate Office of North Carolina, 2015, NC extremesDamaging hurricanes from slopes to shores: State Climate Office of North Carolina web page, accessed November 12, 2016, at http://climate.ncsu.edu/climateblog?id=157. 
State Climate Office of North Carolina, 2016, 1971-2000 climate normals: State Climate Office of North Carolina web page, accessed March 20, 2017, at http://climate.ncsu. edu/cronos/normals.php.

Stradling, Richard, 2016, Hurricane Matthew death toll in $\mathrm{NC}$ rises to 28: The News \& Observer, October 27, 2016, accessed November 9, 2016, at http://www.newsobserver. com/news/weather/article110917747.html.

U.S. Geological Survey, 1985, National Water Summary 1988-89, Hydrologic events and floods and droughts: U.S. Geological Survey Water-Supply Paper 2375, 589 p. (Also available at https://pubs.er.usgs.gov/publication/ wsp2375.)

U.S. Geological Survey, 2016, Short-Term Network data portal: USGS flood information web page, accessed October 21, 2016, at https://water.usgs.gov/floods/FEV.

U.S. Geological Survey, 2017a, 2016 Flood eventsHurricane Matthew: USGS flood information web page, accessed March 20, 2017, at https://water.usgs.gov/floods/ events/2016/matthew/.

U.S. Geological Survey, 2017b, USGS water data for the Nation: U.S. Geological Survey National Water Information System database, accessed March 20, 2017, at https://dx.doi.org/10.5066/F7P55KJN.
Veilleux, A.G., Cohn, T.A., Flynn, K.M., Mason, R.R., Jr., and Hummel, P.R., 2014, Estimating magnitude and frequency of floods using the PeakFQ 7.0 program: U.S. Geological Survey Fact Sheet 2013-3108, 2 p., accessed March 13, 2017, at https://dx.doi.org/10.3133/fs20133108.

Watson, K.M., and Musser, J.W., 2017, Flood inundation, flood depth, and high-water marks for selected areas in North Carolina from the October 2016 flood: U.S. Geological Survey data release, accessed May 2, 2017, at https://doi.org/10.5066/F75X276T.

Weaver, J.C., Feaster, T.D., and Gotvald, A.J., 2009, Magnitude and frequency of rural floods in the South eastern United States, through 2006-Volume 2, North Carolina: U.S. Geological Survey Scientific Investigations Report 2009-5158, 111 p.

Weaver, J.C., Feaster, T.D., and Robbins, J.C., 2016, Preliminary peak stage and streamflow data at selected streamgaging stations in North Carolina and South Carolina for flooding following Hurricane Matthew, October 2016: U.S. Geological Survey Open-File Report 2016-1205, 38 p., accessed March 13, 2017, at https://doi.org/10.3133/ ofr20161205.

Winner, M.D., Jr., and Coble, R.W., 1996, Hydrogeologic framework of the North Carolina Coastal Plain, Regional Aquifer-System Analysis-Northern Atlantic Coastal Plain: U.S. Geological Survey Professional Paper 1404-I, 106 p. + 24 pls. (Also available at https://pubs.usgs.gov/pp/1404i/ report.pdf.) 


\section{Glossary}

The following definitions, except where noted, are from Langbein and Iseri (1960).

cubic feet per second A unit expressing rates of discharge. One cubic foot per second is equal to the discharge of a stream of rectangular cross section, 1 foot wide and 1 foot deep, flowing water an average velocity of 1 foot per second.

flood peak The highest value of the stage or discharge attained by a flood - thus, peak stage or peak discharge. Flood crest has nearly the same meaning, but because it connotes the top of the flood wave, it is properly used only in referring to stage - thus, crest stage, but not crest discharge.

flood exceedance probability The probability that a given event magnitude will be exceeded or equaled in any given year. Flood exceedance probability is directly related to recurrence interval. For example, there is a 1-percent chance that the 100-year peak flow will be exceeded or equaled in any given year. A flood exceedance probability of 0.01 has a recurrence interval of 100 years. The recurrence interval corresponding to a particular flood exceedance probability is equal to one divided by the flood exceedance probability (Interagency Advisory Committee on Water Data, 1982).

gage height The water-surface elevation referred to some arbitrary gage datum. Gage height is often used interchangeably with the more general term stage although gage height is more appropriate when used with a reading on a streamgage.

recurrence interval (return period) The average interval of time within which the given flood will be equaled or exceeded once. The recurrence interval is directly related to the flood exceedance probability. The recurrence interval corresponding to a particular flood exceedance probability is equal to one divided by the flood exceedance probability. For example, a 100-year recurrence interval has a flood exceedance probability of 0.01 (Interagency Advisory Committee on Water Data, 1982). stream A general term for a body of flowing water. In hydrology the term is generally applied to the water flowing in a natural channel as distinct from a canal.

streamflow The discharge that occurs in a natural channel. Although the term discharge can be applied to the flow of a canal, the word streamflow uniquely describes the discharge in a surface stream course.

streamgage For the purposes of this report, the term is used to denote a gaging station where a continuous record of gage height (stage), velocity, or other properties are collected for the purpose of determining streamflow (Interagency Advisory Committee on Water Data, 1982). 
Manuscript approved April 28, 2017

Prepared by the USGS Science Publishing Network Reston Publishing Service Center

Edited by Kay P. Naugle

Illustrations by Jeffrey L. Corbett

For additional information regarding this publication, please contact: Director, South Atlantic Water Science Center

U.S. Geological Survey

720 Gracern Road

Stephenson Center, Suite 129

Columbia, SC 29210

(803) $750-6100$

Or visit the South Atlantic Water Science Center website at

https://www.usgs.gov/water/southatlantic/ 


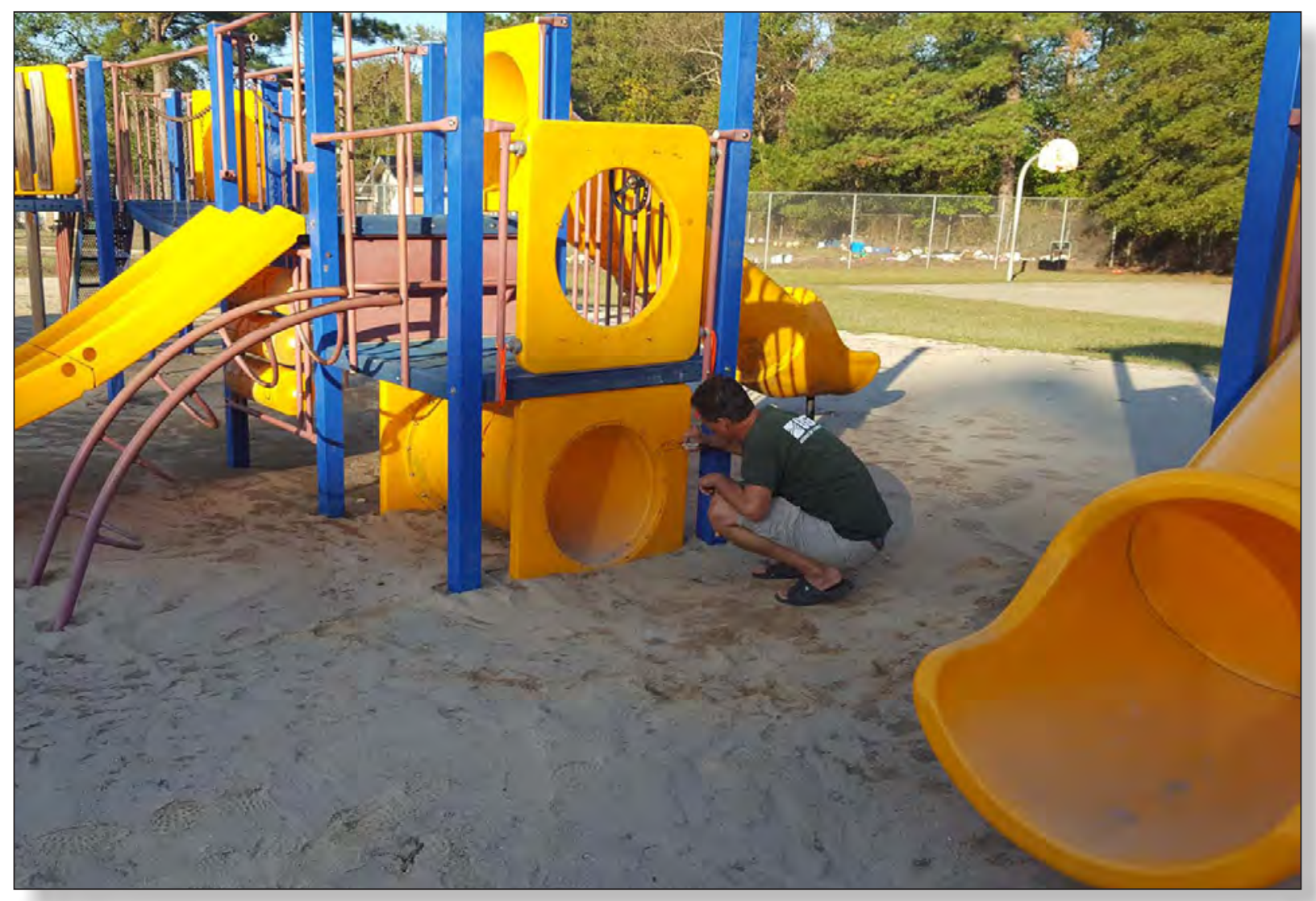

